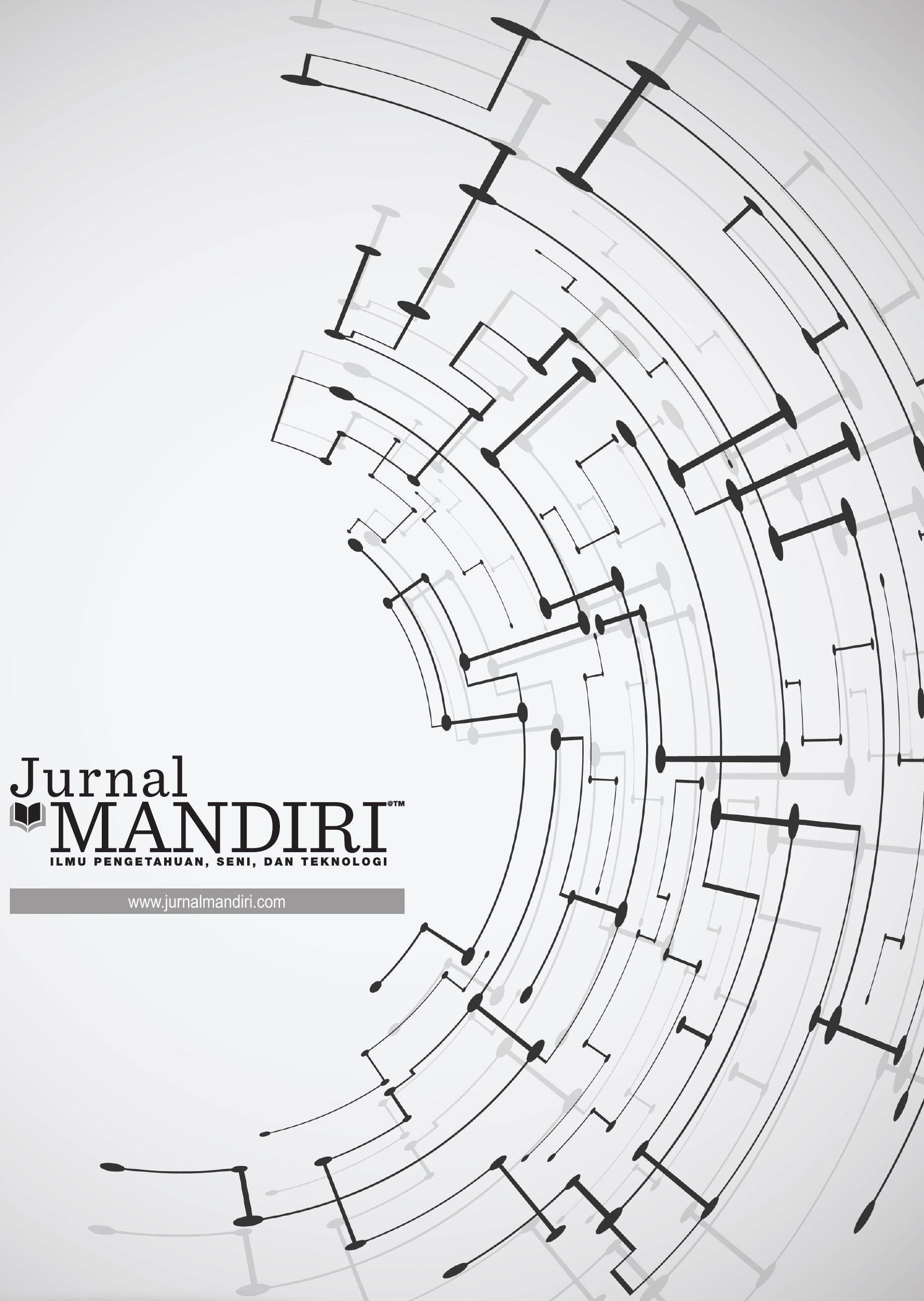


ISSN : 2580-3220, E-ISSN : 2580-4588

J. Mandiri., Vol. 3, No. 1, Juni 2019 (150 - 169)

(C)2018 Lembaga Kajian Demokrasi

dan Pemberdayaan Masyarakat (LKD-PM)

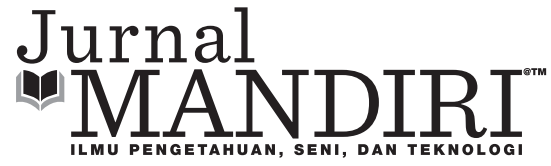

\title{
PENGARUH PELATIHAN DAN DISIPLIN KERJA TERHADAP KINERJA KARYAWAN PADA PT SURYA MUSTIKA NUSANTARA
}

\author{
Ahmad Nazir \\ Fakultas Ekonomi, Universitas Pamulang \\ naziramangkurat@gmail.com
}

\begin{abstract}
Abstrak
Tujuan penelitian ini adalah :Untuk menganalisa Seberapa besar pengaruh pelatihan terhadap efektifitas kinerja karyawan, seberapa besar pengaruh kedisiplinan terhadap efektifitas kinerja karyawan, seberapa besar pengaruh pelatihan dan kedisiplinan terhadap efektifitas kinerja karyawan. Penelitian ini dilakukan pada PT. Surya Mustika Nusantara Ciater.Tangerang Selatan. Metode yang digunakan dalam penelitian ini adalah dengan pendekatan kuantitatif asosiatif yaitu dengan mendeskripsikan keadaan responden serta deskripsi variable penelitian dalam tabel frekuensi dan presentase dari hasil penyebaran angket melalui prosedur analisis data yaitu penelitian lapangan (observasi, wawancara, kuesioner). Populasi sebanyak 140 orang jumlah karyawan dan sampelnya 100 orang dari populasi. Hasil uji korelasi menunjukkan adanya pengaruh yang positif dan signifikan antara Pelatihan $\left(X_{1}\right)$ Terhadap Kinerja karyawan $(Y)$. Bila Pelatihan $\left(X_{1}\right)$ meningkat/ ditingkatkan hingga mendapat nilai 1 , maka Kinerja karyawan $(Y)$ menjadi $: \hat{Y}=54.015+0.080 .1=55.095$ Jadi diperkirakan Kinerja karyawan akan meningkat sebesar 55.095 . Disiplin $\left(X_{2}\right)$ meningkat/ditingkatkan hingga mendapat nilai 1, maka Kinerja karyawan $(Y)$ menjadi $: \hat{Y}=51.769+0.125 .1=52.894$. Jadi diperkirakan Kinerja karyawan akan meningkat sebesar 52.894. Pengaruh Pelatihan $\left(X_{1}\right)$ dan Disiplin $\left(X_{2}\right)$ Terhadap Kinerja karyawan (Y) pengujian korelasi berganda menunjukkan bahwa nilai sig. (2-tailed) antara Pelatihan $\left(X_{1}\right)$ dengan Kinerja karyawan $(Y)$ adalah sebesar $0,002<0,05$ yang berarti terdapat korelasi yang signifikan antara variable pelatihan dengan variable kinerja karyawan.
\end{abstract}

Kata Kunci : Pelatihan, Disiplin, Kinerja dan Karyawan

\section{Abstract}

The purpose of this study is: To analyze how much influence the training has on the effectiveness of employee performance, how much influence the discipline has on the effectiveness of employee performance, how much influence training and discipline have on the effectiveness of employee performance. This research was conducted at PT. Surya Mustika Ciater Nusantara. South Tangerang. The method used in this study is an associative quantitative approach that is by describing the state of the respondent and description of the research variables in the frequency table and the percentage of the results of questionnaires through data analysis procedures, namely field research (observation, interviews, questionnaires). The population is 140 people and the sample is 100 people from the population. The correlation test results show a positive and significant influence between Training $\left(X_{1}\right)$ on employee performance $(Y)$. If Training $\left(X_{1}\right)$ increases / increases to get a value of 1 , then 
employee performance $(Y)$ becomes: $\hat{Y}=54,015+0.080 .1=55,095$ So it is estimated that employee performance will increase by 55,095. Discipline $\left(X_{2}\right)$ increases / increases to get a value of 1 , then employee performance $(Y)$ becomes: $\hat{Y}=51,769+0.125 .1=52,894$. So it is estimated that employee performance will increase by 52,894. Effect of Training $\left(X_{1}\right)$ and Discipline $\left(X_{2}\right)$ on Employee Performance $(Y)$ Multiple correlation testing shows that the value of sig. (2-tailed) between Training $\left(X_{1}\right)$ and Employee Performance $(Y)$ is $0.002<0.05$, which means there is a significant correlation between training variables and employee performance variables.

Keywords : Training, Discipline, Performance and Employees

\section{PENDAHULUAN}

\section{Latar Belakang}

Dalam sebuah perusahaan potensi Sumber Daya Manusia pada dasarnya merupakan salah satu modal dan memegang peran yang paling penting dalam mencapai tujuan perusahaan. Oleh karena itu, perusahaan perlu mengelola Sumber Daya Manusia sebaik mungkin, sebab kunci sukses suatu perusahaan bukan hanya pada keunggulan teknologi dan tersedianya dana saja akan tetapi faktor manusia merupakan faktor yang terpenting. Manusia bisa dikatakan sebagai sumber daya utama yang mampu mengatur, menganalisis dan mengendalikan masalah yang ada di dalam perusahaan. Selain itu manusia mempunyai keinginan, pikiran, perasaan, status dan latar belakang yang beragam yang dibawa ke dalam perusahaan untuk mencapai tujuan perusahaan.

Organisasi perusahaan dapat berjalan sesuai dengan harapan apabila di dalamnya terdapat manusia-manusia dengan satu tujuan yang sama yaitu berkeinginan untuk menjadikan organisasi tempat dia bekerja dan mencari nafkah mengalami peningkatan keuntungan serta perkembangan dari tahun ke tahun. Apabila tujuan dan keinginan itu dapat terwujud, maka sumber daya manusia tersebut tentu berharap hasil jerih payahnya mendapatkan balasan dengan nilai yang sesuai dari organisasi yang telah diperjuangkannya selama ini.

Menurut Wilson Bangun, salah satu sumber daya organisasi yang memiliki peran penting dalam mencapai tujuannya adalah sumber daya manusia. Oleh karena pentingnya peran manusia dalam kompetisi baik jangka pendek maupun jangka panjang dalam agenda bisnis, suatu organisasi harus memiliki nilai lebih dibandingkan dengan organisasi lainnya. Organisasi yang berhasil dalam mempengaruhi pasar jika dapat menarik perhatian atau kelebihan yang dimiliki dalam berbagai hal dibandingkan dengan organisasi lain.

Sumber daya manusia merupakan titik pusat dari seluruh gerak perusahaan, sekaligus sebagai sumber modal dasar atau kekuatan yang merupakan faktor dominan dalam perusahaan. Pembangunan sumber daya manusia menekankan pada karyawan sebagai pelaku pembangunan yang mempunyai profesionalisme, keterampilan, kecakapan, kreativitas, disiplin, serta kemampuan memanfaatkan mengembangkan dan menguasai ilmu pengetahuan dan teknologi yang berwawasan lingkugan, disamping kemampuan dalam pelaksanaan pengelolaannya. Pelatihan dan pengembangan merupakan upaya terencana yang di lakukan perusahaan untuk memfasilitasi pegawai untuk mempelajari berbagai keterampilan dan perilaku yang berhubungan dengan pekerjaan menurut Bernard keys dan Joseph Wolfe dalam Richard L. Draft (2011: 122).

Pelatihan sangat penting bagi pegawai baru maupun pegawai yang sudah lama bekerja. adapun definisi pelatihan menurut Doessler dalam Agusta dan Susanto (2013:1) Pelatihan adalah proses mengajarkan karyawan baru atau yang sudah ada sekarang, keterampilan dasar yang mereka butuhkan untuk menjalankan pekerjaan mereka. Begitu pula dengan halnya Mangkunegara (2009:44) yang memberikan definisi mengenai pelatihan (training) adalah suatu proses pendidikan jangka pendek yang menggunakan prosedur sistematis dan terorganisasi, pegawai non manajerial mempelajari pengetahuan dan 
keterampilan teknis dalam tujuan yang terbatas.

Jenis dan bidang pelatiahan yang di lakukan oleh PT Surya Mustika Nusantara tidak terlepas dari beberapa faktor yang sangat menentukan antara lain tingkat bidang pekerjaan dan tanggungjawabnya dimana karyawan tersebut melakukan pekerjaanya. Meningkat atau lebih baik dari pada sebelum di lakukan pelatihan.

Salah satu faktor yang sangat berpengaruh dalam sumber daya manusia adalah faktor kedisiplinan. Menurut Hasibuan, kedisiplinan merupakan fungsi Manajemen Sumber Daya Manusia yang terpenting dan kunci terwujudnya tujuan karena tanpa disiplin yang baik sulit terwujud tujuan yang maksimal.

Disiplin kerja dapat dilihat sebagai sesuatu yang besar manfaatnya, baik bagi kepentingan organisasi maupun bagi para karyawan. Bagi organisasi adanya disiplin kerja akan menjamin terpeliharanya tata tertib dan kelancaran pelaksanaan tugas, sehingga diperoleh hasil yang optimal. Adapun bagi karyawan diperoleh suasana kerja yang menyenangkan sehingga akan menambah semangat kerja dalam melaksanakan pekerjaannya. Dengan demikian, karyawan dapat melaksanakan tugasnya dengan penuh kesadaran serta dapat mengembangkan tenaga dan pikirannya semaksimal mungkin demi terwujudnya tujuan organisasi.

Sutrisno, mengatakan bahwa disiplin karya-

\begin{tabular}{|c|c|c|c|c|c|c|c|}
\hline \multicolumn{8}{|c|}{$\begin{array}{r}\text { Tabel 1. Tingkat Kedisiplinan Karyawan PT Surya Mu } \\
\text { Periode Juli } 2018 \text { - Desember } 2018\end{array}$} \\
\hline \multirow[b]{2}{*}{ BULAN } & \multirow{2}{*}{$\begin{array}{l}\text { JUMLAH } \\
\text { KARYA } \\
\text { WAN }\end{array}$} & \multicolumn{2}{|c|}{ TERLAMBATDATANG } & \multicolumn{2}{|c|}{ SAKIT } & \multicolumn{2}{|c|}{ ALPA } \\
\hline & & $\begin{array}{l}\text { JUMLAH } \\
\text { KARYA } \\
\text { WAN }\end{array}$ & PRESENTASE & $\begin{array}{l}\text { JUMLAH } \\
\text { KARYA } \\
\text { WAN }\end{array}$ & PRESENTASE & $\begin{array}{l}\text { JUMLAH } \\
\text { KARYA } \\
\text { WAN }\end{array}$ & PRESENTASE \\
\hline JANUARI & 150 & 94 & $62.67 \%$ & 22 & $14.67 \%$ & 15 & $10.00 \%$ \\
\hline FEBRUARI & 150 & 96 & $64.00 \%$ & 26 & $17.22 \%$ & 7 & $4.67 \%$ \\
\hline MARET & 150 & 80 & $53.33 \%$ & 16 & $10.67 \%$ & 13 & $8.67 \%$ \\
\hline APRLL & 150 & 57 & $38.00 \%$ & 18 & $12.00 \%$ & 16 & $10.67 \%$ \\
\hline MEl & 150 & 68 & $45.33 \%$ & 13 & $8.67 \%$ & 10 & $6.67 \%$ \\
\hline JUNI & 150 & 70 & $46.67 \%$ & 20 & $13.33 \%$ & 10 & $6.67 \%$ \\
\hline JULI & 150 & 92 & $61.33 \%$ & 13 & $8.67 \%$ & 35 & $23.33 \%$ \\
\hline AGUSTUS & 150 & 91 & $60.67 \%$ & 35 & $23.33 \%$ & 56 & $37.33 \%$ \\
\hline SEPTEMBER & 150 & 89 & $59.33 \%$ & 30 & $20.00 \%$ & 20 & $13.33 \%$ \\
\hline OKTOBER & 150 & 79 & $52.67 \%$ & 17 & $11.33 \%$ & 36 & $24.00 \%$ \\
\hline \multirow{2}{*}{\multicolumn{2}{|c|}{ AVERAGE }} & 825 & $544.00 \%$ & 210 & $140.00 \%$ & 218 & $145.33 \%$ \\
\hline & & 82.5 & $54.40 \%$ & 21 & $14.00 \%$ & 21.8 & $14.53 \%$ \\
\hline
\end{tabular}

wan adalah perilaku seseorang dengan peraturan, prosedur kerja yang ada atau disiplin adalah sikap, tingkah laku dan perbuatan yang sesuai dengan peraturan dari organisasi baik tertulis maupun tidak tertulis.

Kinerja diartikan sebagai sesuatu yang dapat dicapai. Dari penjelasan yang telah diartikan kamus lengkap Bahasa Indonesia kinerja dapat diperoleh pengertian bahwa kinerja adalah hasil kerja yang dapat dicapai oleh seseorang atau sekelompok orang dalam suatu organisasi, sesuai wewenang dan tanggung jawab masing-masing, dalam rangka upaya mencapai tujuan organisasi bersangkutan secara legal, tidak melanggar hukum dan sesuai dengan moral maupun etika. Jadi yang dimaksud dengan kinerja dalam skripsi ini adalah sebuah hasil yang telah dicapai oleh seseorang atau sekelompok orang yang berada dalam lingkungan yang sama yaitu lingkungan kerja untuk mencurahkan seluruh kemampuannya demi kemajuan organisasi.

Pada penelitian kali ini, PT Surya Mustika Nusantara (Grup Gudang Garam) dipilih sebagai objek penelitian, perusahaan ini merupakan perusahaan Sales \& Marketing terkemuka di Indonesia yang bertanggungjawab dalam penjualan, promosi dan distribusi produk PT. Karyadibya Mahardhika seperti Apache dan Extreme Mild. Perusahaan ini di tuntut untuk mendistribusikan produknya secara nasional dengan ratusan kantor pemasaran dan puluhan agen penjualan diseluruh Indonesia memberikan kualitas pemasaran yang terbaik untuk mencapai omset penjualan. Oleh karena itu dibutuhkan sumber daya manusia (SDM) yang handal, kompeten, professional, dan berkualitas.

Dalam hal kompetensi sumber daya manusia, kinerja karyawan merupakan unsur penting demi terciptanya tujuan perusahaan. Kinerja karyawan yang tinggi sangatlah diharapkan oleh PT Surya Mustika Nusantara. Semakin banyak karyawan yang mempunyai kinerja tinggi, maka produktifitas perusahaan secara keseluruhan akan meningkat sehingga perusahaan akan dapat bertahan dalam persaingan global. Karyawan dituntut untuk mampu menyelesaikan tugas dan tanggung jawabnya secara efektif dan efisien. 
Keberhasilan karyawan dapat diukur melalui kepuasan konsumen, berkurangnya jumlah keluhan dan tercapainya target penjualan yang optimal. Kinerja karyawan PT. Surya Mustika Nusantara juga dapat diukur melalui penyelesaian tugasnya secara efektif dan efisien serta melakukan peran dan fungsinya dan itu semua berhubungan positif bagi keberhasilan suatu perusahaan. Terdapat faktor negatif yang dapat menurunkan kinerja karyawan, diantaranya adalah menurunnya keinginan karyawan untuk mencapai prestasi kerja, kurangnya ketepatan waktu dalam penyelesaian pekerjaan sehingga kurang mentaati peraturan, pengaruh yang berasal dari lingkungannya, teman sekerja yang juga menurun semangatnya dan tidak adanya contoh yang harus dijadikan acuan dalam pencapaian prestasi kerja yang baik serta hubungan sesama rekan kerja yang kurang harmonis. Semua itu merupakan sebab menurunnya kinerja karyawan dalam bekerja.

Permasalahan disiplin kerja pada PT Surya Mustika Nusantara dapat dilihat Dari hasil pra survei diperoleh informasi bahwa beberapa karyawannya menunjukkan kinerja yang kurang maksimal, seperti terlambat hadir, tidak berada di tempat pada saat jam kerja, sakit tanpa surat dokter dan alpa. Oleh karena itu bila hal ini terus berlanjut dan tidak ada solusinya, maka dikhawatirkan setiap individu tidak disiplin atau kinerjanya tidak baik yang akan berdampak pada kinerja organisasi secara keseluruhan.

\section{Rumusan Masalah}

1. Seberapa besar pengaruh pelatihan terhadap efektifitas kinerja karyawan.

2. Seberapa besar pengaruh kedisiplinan terhadap efektifitas kinerja karyawan.

3. Seberapa besar pengaruh pelatihan dan kedisiplinan terhadap efektifitas kinerja karyawan.

\section{Tujuan Penulisan}

1. Untuk menganalisa Seberapa besar pengaruh pelatihan terhadap efektifitas kinerja karyawan.

2. Untuk menganalisa Seberapa besar pengaruh kedisiplinan terhadap efektifitas kinerja karyawan.

3. Untuk menganalisa Seberapa besar pengaruh pelatihan dan kedisiplinan terhadap efektifitas kinerja karyawan.

\section{Pengertian Pelatihan}

Menurut pasal 1 ayat 9 undang-undang No. 13 tahun 2003 (ketenagakerjaan) pelatihan kerja adalah keseluruhan kegiatan untuk memberi, memperoleh, meningkatkan, serta mengembangkan kompetensi kerja, produktivitas, disiplin, sikap, dari etos kerja pada tingkat keterampilan dan keahlian tertentu sesuai dengan jenjang dan kualifikasi jabatan dan pekerjaan.

Menurut Mathis (2002), Pelatihan adalah suatu proses dimana orang-orang mencapai kemampuan tertentu untuk membantu mencapai tujuan organisasi. Oleh karena itu, proses ini terikat dengan berbagai tujuan organisasi, pelatihan dapat dipandang secara sempit maupun luas. Secara terbatas, pelatihan menyediakan para pegawai dengan pengetahuan yang spesifik dan dapat diketahui serta keterampilan yang digunakan dalam pekerjaan mereka saat ini. Terkadang ada batasan yang ditarik antara pelatihan dengan pengembangan, dengan pengembangan yang bersifat lebih luas dalam cakupan serta memfokuskan pada individu untuk mencapai kemampuan baru yang berguna baik bagi pekerjaannya saat ini maupun di masa mendatang.

Sedangkan Payaman Simanjuntak (2005) mendefinisikan pelatihan merupakan bagian dari investasi SDM (human investment) untuk meningkatkan kemampuan dan keterampilan kerja, dan dengan demikian meningkatkan kinerja pegawai. Pelatihan biasanya dilakukan dengan kurikulum yang disesuaikan dengan kebutuhan jabatan, diberikan dalam waktu yang relatif pendek, untuk membekali seseorang dengan keterampilan kerja. Maka oleh karna itu dapat disimpulkan bahwa pelatihan adalah suatu usaha dalam meningkatkan sumber daya manusia dalam dunia usaha. Karyawan baik yang baru maupun yang lama perlu mengikuti pelatihan karena adanya tuntutan pekerjaan yang dapat 
berubah akibat perubahan lingkungan kerja, strategi dan sebagainya.

Peserta yang akan mengikuti program pelatihan dikelompokan menjadi dua, yaitu:

1. Karyawan baru yaitu karyawan yang baru diterima bekerja pada perusahaan. Mereka diberi pelatihan terlebih dahulu sebelum bekerja agar lebih terampil dan ahli dalam menyelesaikan pekerjaannya, sehingga para karyawan dapat bekerja lebih efektif dan efisien.

2. Karyawan lama yaitu karyawan yang telah bekerja lama disebuah perusahaan dan karyawan tersebut ditugaskan untuk mengikuti pelatihan. Pelatihan karyawan lama dilakukan karena tuntutan pekerjaan misalnya kenaikan jabatan, perluasaan perusahaan, pembaharuan metode kerja, serta persiapan untuk promosi. Jelasnya pelatihan pada karyawan lama perlu dilaksanakan agar para karyawan semakin memahami keahlian kerja pada bidangnya masing-masing, agar moral kerja dan prestasi kinerja karyawan semakin meningkat.

\section{Tujuan Pelatihan Karyawan}

Menurut pasal 9 undang-undang ketenagakerjaan tahun 2003, pelatihan kerja diselenggarakan dan diarahkan untuk membekali, meningkatkan, dan mengembangkan kompetensi kerja guna meningkatkan kemampuan, produktivitas, dan kesejahteraan. Tujuan-tujuan pelatihan pada intinya dapat dikelompokkan kedalam lima bidang, yaitu:

1. Memperbaiki kinerja. Karyawan-karyawan yang bekerja secara tidak memuaskan karena kekurangan keterampilan merupakan calon utama pelatihan kendatipun pelatihan tidak dapat memecahkan semua masalah kinerja yang tidak efektif, program pelatihan dan pengembangan yang sehat sering berfaedah dalam meminimalkan masalah ini.

2. Memutakhirkan para karyawan sejalan dengan kemajuan teknologi, Melalui pelatihan, pelatih (trainer) memastikan bahwa karyawan dapat mengaplikasikan teknologi baru secara efektif. Para manajer di se- mua bidang haruslah secara konstan mengetahui kemajuan teknologi yang membuat organisasi mereka berfungsi secara lebih efektif. Perubahan teknologi, pada gilirannya, berarti bahwa pekerjaan senantiasa berubah dan keahlian serta kemampuan karyawan haruslah dimutakhirkan melalui pelatihan, sehingga kemajuan teknologi dapat diintegrasikan kedalam organisasi secara sukses.

3. Mengurangi waktu pembelajaran bagi karyawan baru agar kompeten dalam pekerjaan. Seorang karyawan baru acapkali tidak menguasai keahlian dan kemampuan yang dibutuhkan untuk menjadi "job competen", yaitu mampu mencapai output dan standar mutu yang diharapkan.

4. Membantu memecahkan masalah operasional. Para manajer harus mencapai tujuan mereka dengan kelangkaan dan kelimpahan sumberdaya. Kelangkaan sumber daya finansial dan sumber daya teknologis manusia (human technological resources), dan kelimpahan masalah keuangan, manusia, dan teknologis.

5. Mempersiapkan karyawan untuk promosi. Salah satu cara untuk menarik, menahan, dan memotivasi karyawan adalah melalui program pengembangan karir yang sistematik. Pengembangan kemampuan promosional karyawan konsisten dengan kebijakan sumber daya manusia untuk promosi dari dalam, pelatihan adalah unsur kunci dalam sistem pengembangan karir.

6. Mengorientasikan karyawan terhadap organisasi. Selama beberapa hari pertama di pekerjaan, karyawan baru membentuk kesan pertama mereka terhadap organisasi dan tim manajemen. Kesan ini dapat meliputi kesan yang menyenangkan sampai yang tidak mengenakkan, dan dapat mempengaruhi kepuasan kerja dan keseluruhan produktivitas karyawan. Karena alesan inilah, beberapa penyelenggara orientasi melakukan upaya bersama dengan tujuan mengorientasikan para karyawan baru terhadap organisasi dan pekerjaan secara benar. 
7. Memenuhi kebutuhan pertumbuhan pribadi. Misalnya, sebagian besar manajer adalah berorientasi pencapaian dan membutuhkan tantangan baru di pekerjaannya, Pelatihan dan pengembangan dapat memainkan peran ganda dengan menyediakan aktivitas-aktivitas yang menghasilkan efektivitas organisasional yang lebih besar dan meningkatkan pertumbuhan pribadi bagi semua karyawan.

\section{Manfaat Pelatihan}

Pelatihan mempunyai andil besar dalam menentukan efektivitas dan efesiensi organisasi. Beberapa manfaat nyata yang ditangguk dari program pelatihan dan pengembangan adalah:

a. Meningkatkan kuantitas dan kualitas produktivitas

b. Mengurangi waktu belajar yang diperlukan karyawan untuk mencapai standar kinerja yang dapat diterima

c. Membentuk sikap, loyalitas, dan kerja sama yang menguntungkan

d. Memenuhi kebutuhan perencanaan sumber daya manusia

e. Mengurangi frekuensi dan biaya kecelakaan kerja

f. Membantu karyawan dalam peningkatan dan pengembangan pribadi mereka

\section{Indikator Pendidikan dan Pelatihan Menurut Sedarmayanti}

Menurut Sedarmayanti dalam bukunya manajemen sumber daya manusia (2013:174) mengemukakan beberapa indikator pendidikan dan pelatihan diantaranya:

a. Penyelenggara pelaksanaan

Kegiatan pengamatan, pengolahan data, pelayanan, penelitian, rekayasa, dan pengembangan, serta kerja sama dalam bidang pendidikan dan pelatihan.

b. Kebutuhan

Suatu keinginan terhadap benda atau jasa yang pemuasannya dapat dilakukan baik bersifat jasmani maupun rohani.

c. Kualitas pengajar

Merupakan salah satu aspek dari pen- didikan, yaitu aspek pengetahuan. Pengajaran memberikan keterampilan dan pengetahuan, sedangkan pendidikan membimbing pegawai kearah yang tidak baik dan benar.

\section{Pengertian Disiplin}

Disiplin adalah kepatuhan pada aturan atau perintah yang ditetapkan oleh organisasi. Disiplin merupakan sebuah proses yang digunakan untuk menghadapi permasalahan kinerja dimana proses ini melibatkan pimpinan atau manajer dalam mengidentifikasi dan mengkomunikasikan masalah-masalah kinerja kepada para karyawan.

Disiplin menurut Keiht Davis, sebagaimana yang dikutip oleh A. A Anwar Prabu Mangkunegara (2013:129) bahwa "Disciplin is management action to enforce organization standarts". Berdasarkan pendapat Keiht Davis, disiplin kerja dapat diartikan sebagai pelaksanaan manajemen untuk memperteguh pedomanpedoman organisasi.

Setiap organisasi ataupun perusahaan pasti memiliki standar atas perilaku setiap karyawannya dalam melaksakan pekerjaannya, baik secara lisan maupun tulisan dan menginginkan setiap pegawai untuk mematuhinya sebagai salah satu upaya untuk meningkatkan produktivitas. Meskipun dalam kenyataan sering terjadi adanya tindakan indisipliner yang dilakukan oleh karyawannya. Oleh karena itu peningkatan disiplin pegawai sangat penting dalam proses sumber daya manusia sebagai faktor dalam peningkatan produktivitas.

Berdasarkan teori diatas maka peneliti dapat mengambil kesimpulan bahwa disiplin merupakan salah satu kunci keberhasilan suatu perusahaan ataupun organisasi dalam mewujudkan tujuannya.

\section{Macam-macam Disiplin}

Dalam bukunya, Anwar Prabu Mangkunegara (2013:129-130) ada 2 (dua) bentuk disiplin kerja, yaitu :

a. Disiplin Preventif

Disiplin preventif adalah suatu upaya untuk menggerakkan pegawai mengikuti dan mematuhi pedoman kerja, aturan- 
aturan yang telah digariskan oleh perusahaan. Tujuan dasarnya adalah untuk menggerakkan pegawai berdisiplin diri. Dengan cara preventif, pegawai dapat memelihara dirinya terhadap peraturan-peraturan perusahaan. Pemimpin perusahaan mempunyai tanggung jawab dalam membangun iklim organisasi dengan disiplin preventif, begitu pula pegawai harus dan wajib mengetahui, memahami semua pedoman kerja serta peraturan-peraturan yang ada dalam organisasi. Disiplin preventif merupakan suatu sistem yang berhubungan dengan kebutuhan kerja untuk semua bagian sistem yang ada dalam organisasi. Jika sistem organisasi baik, maka diharapkan akan lebih mudah menegakkan disiplin kerja.

b. Disiplin Korektif

Disiplin korektif adalah suatu upaya menggerakkan pegawai dalam menyatukan suatu peraturan dan mengarahkan untuk tetap mematuhi peraturan sesuai dengan pedoman yang berlaku pada perusahaan.Pada disiplin korektif, pegawai yang melanggar disiplin perlu diberikan sanksi sesuai dengan peraturan yang berlaku.Tujuan pemberian sanksi adalah untuk memperbaiki pegawai pelanggar, memelihara peraturan yang berlaku dan memberikan pelajaran kepada pelanggar.

\section{Pendekatan Disiplin}

Ada 3 (tiga) pendekatan disiplin, menurut Anwar Prabu Mangkunegara (2013:130-131), yaitu :

a. Pendekatan disiplin modern

Pendekatan disiplin modern yaitu mempertemukan sejumlah keperluan atau kebutuhan baru di luar hukuman. Pendekatan ini berasumsi :

1. Disiplin modern merupakan suatu cara menghindarkan bentuk hukuman secara fisik.

2. Melindungi tuduhan yang benar untuk diteruskan pada proses hukuman yang berlaku.

3. Keputusan-keputusan yang semaunya terhadap kesalahan atau prasangka harus diperbaiki dengan mengadakan proses penyuluhan dengan mendapatkan fakta-faktanya.

4. Melakukan protes terhadap keputusan yang berat sebelah pihak terhadap kasus disiplin.

b. Pendekatan Disiplin dengan Tradisi

Pendekatan disiplin dengan tradisi, yaitu pendekatan disiplin dengan cara pemberian hukuman. Pendekatan ini berasumsi :

1. Disiplin dilakukan oleh atasan kepada bawahan, dan tidak pernah ada peninjauan kembali bila telah diputuskan.

2. Disiplin adalah hukuman untuk pelanggaran, pelaksanaannya harus disesuaikan dengan tingkat pelanggarannya.

3. Pengaruh hukuman untuk memberikan pelajaran kepada pelanggar maupun kepada pegawai lainnya.

4. Pengingkatan perbuatan pelanggaran diperlukan hukuman yang lebih keras.

5. Pemberian hukuman terhadap pegawai yang melanggar kedua kalinya harus diberi hukuman yang lebih berat.

c. Pendekatan Disiplin Bertujuan

Pendekatan disiplin bertujuan berasumsi bahwa :

1. Disiplin kerja harus dapat diterima dan dipahami oleh semua pegawai.

2. Disiplin bukanlah suatu hukuman, tetapi merupakan pembentukan perilaku.

3. Disiplin ditujukan untuk perubahan perilaku yang lebih baik.

4. Disiplin pegawai bertujuan agar pegawai bertanggung jawab terhadap perbuatannya.

\section{Indikator-indikator Disiplin}

Menurut hasibuan (2013:194) pada dasarnya banyak indkator-indikator yang mempengaruhi tingkat disiplin karyawan, diantaranya adalah :

1. Tujuan dan kemampuan

Tujuan dan kemampuan ikut mempengaruhi tingkat kedisiplinan karyawan. Tujuan yang akan dicapai harus jelas dan ditetapkan secara ideal serta cukup menantang bagi ke- 
mampuan karyawan. Hal ini berarti bahwa tujuan (pekerjaan) yang dibebankan kepada karyawan harus sesuai dengan kemampuan karyawan bersangkutan, agar dia bekerja dengan sungguh-sungguh dan disiplin dalam mengerjakannya.

2. Teladan pimpinan

Teladan pimpinan sangat berperan dalam menentukan kedisiplinan karyawan, karena pimpinan dijadikan teladan dan panutan oleh para bawahannya. Pimpinan harus memberi contoh yang baik, berdisiplin baik, jujur, adil, serta sesuai kata dengan perbuatan. Dengan teladan pimpinan yang baik, kedisiplinan bawahan pun akan baik. Jika teladan pimpinan kurang baik (kurang berdisiplin), para bawahan pun akan kurang disiplin.

3. Balas jasa

Balas jasa (gaji dan kesejahteraan) ikut mempengaruhi kedisiplinan karyawan karena balas jasa akan memberikan kepuasan dan kecintaan karyawan terhadap perusahaan pekerjaannya. Jika kecintaan karyawan semakin baik terhadap pekerjaan, kedisiplinan mereka akan semakin baik pula. Balas jasa berperan penting untuk menciptakan kedisiplinan karyawan. Artinya semakin besar balas jasa, semakin baik kedisiplinan karyawan. Sebaliknya, apabila balas jasa kecil, kedisiplinan karyawan menjadi rendah. Karyawan sulit untuk berdisiplin baik selama kebutuhan-kebutuhan primernya tidak terpenuhi dengan baik.

4. Keadilan

Keadilan ikut mendorong terwujudnya kedisiplinan karyawan, karena ego dan sifat manusia yang selalu merasa dirinya penting, dan minta diperlakukan sama dengan manusia lainnya. Keadilan yang dijadikan dasar kebijaksanaan dalam pemberian balas jasa (pengakuan) atau hukuman, akan merangsang terciptanya kedisiplinan karyawan yang baik. Manajer yang cakap dalam memimpin selalu berusaha bersikap adil terhadap semua bawahannya. Dengan keadilan yang baik, akan menciptakan kedisiplinan yang baik pula. Jadi, keadilan harus diterapkan dengan baik pada setiap perusahaan agar kedisiplinan karyawan perusahaan baik pula.

5. Waskat

Waskat (pengawasan melekat) adalah tindakan nyata dan paling efektif dalam mewujudkan kedisiplinan karyawan perusahaan. Dengan waskat berarti atasan harus aktif dan langsung mengawasi perilaku, moral, sikap, gairah kerja, danprestasi kerja bawahannya. Hal ini berarti atasan harus selau hadir di tempat kerja agar dapat mengawasi dan memberikan petunjuk jika ada bawahannya yang mengalami kesulitan dalam menyelesaikan pekerjaannya. Waskat efektif merangsang kedisiplinan dan moral kerja karyawan. Karyawan merasa mendapat perhatian, bimbingan, petunjuk, pengarahan dan pengawasan dari atasannya.

\section{Prinsip-Prinsip Disiplin}

Simamora Barnawi \& Arifin, 2012:119 terdapat tujuh prinsip baku yang perlu diperhatikan dalam pengelolaan disiplin pegawai, yaitu:

a. Prosedur dan kebijakan yang pasti

Pemimpin perlu memberikan perhatian yang serius terhadap berbagai keluhan bawahan. Hal ini mendorong pertumbuhan disiplin kerja. Pimpinan perlu menentukan jenis perilaku yang dikehendaki dan bagaimana cara melakukanya. Prosedur-prosedur disiplin harus mengikuti aturan yang sudah disepakati dari awal.Pimpinan harus berpegang teguh terhadap aturan yang sudah ada dan konsisten dalam pelaksanaanya. Tujuan dibuatnya prosedur dan kebijakan yang pasti adalah untuk menciptakan bentuk disiplin yang konstruktif dan positif melalui kepemimpinan yang sehat dan pelatihan yang memandai bagi para karyawan.

b. Tanggung jawab kepengawasan

Tanggung jawab kepengawasan harus diperhatikan baik-baik. Untuk menjaga disiplin kerja, perlu ada pengawasan yang memiliki otoritas dalam memberikan peringatan 
lisan maupun tulisan. Sebelum memberikan teguran, biasanya pengawas berkonsultasi terlebih dahulu dengan atasannya.

c. Komunikasi berbagai peraturan

Para bawahan hendaknya memahami peraturan dan standar disiplin serta konsekuensi pelanggannya.Setiap bawahan hendakanya memahami secara penuh kebijakan-kebijakan dan prosedur-prosedur disiplin.Kebijakan dan prosedur tersebut dapat disosialisasikan melalui buku manual kerja bawahan.

d. Tanggung jawab pemaparan bukti Setiap bawahan haruslah dianggap tidak bersalah samapai benar-benar ada bukti bawahan karyawan tersebut dinyatakan bersalah. Hukuman baru bisa dijatuhkan apabila bukti-bukti telah terkumpul secara menyakinkan. Perlu diperhatikan bahwa bukti tersebut hendaknya didokumentasikan secara cermat sehingga sulit untuk dipertentangkan. Selain itu, bawahan yang diduga bersalah harus diberi kesempatan untuk membela diri dan mendapat pembelaan.

e. Perlakuan yang konsisten

Konsisten peraturan merupakan salah satu prnsip yang penting, tetapi sering diabaikan. Segala peraturan dan hukuman harus diberlakukan secara konsisten tanpa diskriminasi. Pemberlakuan aturan yang berbeda antara satu pihak dengan pihak yang lain akan merusak efektivitas dari sistem disiplin. Inkonsistensi dalam penegakan peraturan akan menciptakan kecemburuan sosial antara para karyawan.

f. Pertimbangan atas berbagai situasi

Konsistensi pemberlakuan peraturan bukanlah berarti memberi hukuman yang sana pada pelanggaran yang identik. Besarnya hukuman perlu mempertimbangkan berbagai faktor. Situasi di lapangan dan faktafakta yang menggambarkan pelanggaran patut menjadi pertimbangan dalam pemberian hukuman.

g. Peraturan dan hukuman yang masuk akal Peraturan dan hukuman hendakanya di- buat secara masuk akal. Peraturan dan hukuman yang masuk akal akan membuat orang mudah menerimanya. Hukuman hendaknya wajar. Hukuman berat yang diberikan kepada bawahan yang melakukan pelanggaran ringan justru akan menciptakan perasaan tidak adil diantara para bawahan. Peraturan dan hukuman yang tidak wajar akan menimbulakan sikap negatif diantara para bawahan dan menumbuhkan sikap tidak kooperatif terhadap atasannya.

\section{Pengertian Kinerja}

Pengertian kinerja adalah hasil kerja yang dapat dicapai oleh seseorang atau kelompok orang dalam suatu organisasi, sesuatu dengan wewenang dan tanggung jawab masing-masing, dalam upaya mencapai tujuan organisasi bersangkutan secara legal, tidak melanggar hokum dan sesuai dengan moral ataupun etika.

Kinerja menurut Malayu S.P Hasibuan (2013:34) Kinerja merupakan suatu hasil kerja yang di capai seseorang dalam melaksanakan tugas-tugasnya atas kecakapan, usaha dan kesempatan. Berdasarkan paparan diatas kinerja adalah suatu hasil yang di capai seseorang dalam melaksanakan tugas-tugas yang berdasarkan atas kecakapan, pengalaman dan kesungguhan serta waktu menurut standard kinerja yang telah di tetapkan sebelumnya.

Anwar Prabu Mangkunegara (2013:67) menyatakan bahwa kinerja adalah hasil kerja secara kualitas dan kuantitas yang di capai oleh seorang karyawan dalam melaksanakan tugasnya sesuai dengan tanggung jawab yang di berikan kepadanya.

Menurut Sedarmayanti (2013:176) Mendefinisikan kinerja sebagai hasil kerja yang dapat dicapai oleh seseorang atau sekelompok orang dalam suatu organisasi, sesuai dengan wewenang dan tanggung jawab masing-masing dalam upaya mencapai tujuan organisasi bersangkutan secara legal, tidak melanggar hukum sesuai dengan norma maupun etika.

Ada dua jenis perilaku atau tugas mencakup unsur-unsur penting kinerja karyawan, yaitu tugas fungsional atau tugas perilaku. Tugas 
fungsional berhubungan dengan seberapa baik seorang karyawan menyelesaikan suatu pekerjaan, terutama menyelesaikan aspek-aspek yang bersifat teknis dari pekerjaan yang menjadi tanggung jawabnya. Sedangkan tugas perilaku berhubungan dengan seberapa baik karyawan menangani kegiatan antar pribadi dengan anggota yang lain termasuk menangani konflik mengelola waktu, bekerja dalam kelompok dan bekerja sendiri. Hal tersebut sangat bergantung kepada seberapa besar motivasi yang mereka miliki yang dapat menimbulkan peningkatan vitalitas dan kemampuan untuk bekerja keras.

\section{Penilaian Kinerja}

Penilaian kinerja merupakan sebuah proses formal untuk melakukan peninjauan ulang dan mengevaluasi kinerja seorang secara periodik. Proses adalah suatu cara yang sistematis atau langkah-langkah yang diikuti dalam melakukan sesuatu. Proses penilaian kinerja ditujukan untuk memahami prestasi kerja seseorang. Tujuan ini memerlukan sebuah proses, yaitu serangkaian kegiatan yang saling berkaitan. Kegiatan-kegiatan ini terdiri dari identifikasi, observasi, pengukuran dan pengembangan hasil kerja karyawan dalam sebuah organisasi.

\section{Indikator-indikator Kinerja}

Yang menjadi indikator-indikator Kinerja menurut Anwar Prabu (2013:67) adalah sebagai berikut:

a. Tanggung Jawab

Tanggung Jawab adalah kesanggupan seorang tenaga kerja dalam menyelesaikan tugas dan pekerjaan yang di serahkan kepadanya dengan sebaik-baiknya dan tepat waktu serta berani membuat risiko atas keputusan yang di ambilnya. Tanggung jawab dapat merupakan keharusan pada seorang karyawan untuk melakukan secara layak apa yang telah diwajibkan padanya.

b. Disiplin

Disiplin adalah suatu sikap menghormati, menghargai, patuh dan taat terhadap peraturan-peraturan yang berlaku baik tertulis maupun tidak tertulis dan di kenai sanksi apabila melanggar tugas dan wewenang yang di berikan kepadanya.

c. Pencapaian Target

Pencapaian Target adalah suatu proses kegiatan yang mana bertujuan untuk mendapatkan suatu hasil sesuai dengan rencana atau program yang telah di tetapkan.

d. Kejujuran

Kejujuran adalah ketulusan hati seorang tenaga kerja dalam melaksanakan tugas dan pekerjaan serta kemampuan untuk tidak mwenyalah gunakan wewenang yang telah di berikan kepadanya.

e. Motivasi

Motivasi adalah suatu sugesti atau dorongan yang muncul karena di berikan oleh seseorang kepada orang lain atau dari diri sendiri, dorongan tersebut bermaksud agar orang tersebut menjadi orang yang lebih baik dari yang sebelumnya.

\section{METODE}

\section{A. Ruang Lingkup Penelitian}

1. Tempat Penelitian

Penelitian ini dilakukan pada PT. Surya Mustika Nusantara beralamat di Jl. Raya Masjid An-nur RT.009/RW.010 Pondok Sentul No.10 Ciater.Tangerang Selatan, 15317

2. Waktu Penelitian

Waktu penelitian yang digunakan untuk penelitian pengaruh disiplin kerja terhadap kinerja karayawan pada PT. Surya Mustika Nusantara - Tangerang Selatan. Penelitian ini dilakukan pada bulan Juli-Desember 2018 hingga tercukupi kebutuhan data dan informasi.

3. Jenis Penelitian

Metode penelitian yang digunakan dalam penelitian ini adalah dengan pendekatan kuantitatif asosiatif yaitu dengan mendeskripsikan keadaan responden serta deskripsi variable penelitian dalam tabel frekuensi dan presentase dari hasil penyebaran angket dengan melalui prosedur analisis data yaitu penelitian lapangan (observasi, wawancara, kuesioner). 


\section{B. Metode Penentuan Populasi Dan Sampel}

1. Populasi

Menurut Sugiyono (2010:115-116) populasi adalah wilayah generalisasi yang terdiri atas objek dan subjek yang mempunyai kuantitas dan karakteristik tertentu yang ditetapkan oleh peneliti untuk dipelajari dan kemudian ditarik kesimpulan populasi dalam penelitian ini adalah 140 orang.Yang meliputi karyawan dan supervisor

2. Sampel Penelitian

Menurut Sugiyono (2012:91) sampel adalah bagian dari jumlah dan karakteristik yang dimiliki oleh populasi tersebut.

Menurut Suharsimi Arikunto (2010: 112), jika subjeknya kurang dari 100 orang sebaiknya di ambil semuanya, jika subjeknya besar atau lebih dari 100 orang dapat di ambil $10-15 \%$ atau $20-25 \%$ atau lebih. Melihat jumlah populasi karyawan yang berjumlah 140 orang karyawan maka dalam menentukan jumlah sampel dalam penelitian ini peneliti menggunakan teknik proportionate stratified sampling teknik ini digunakan karena populasi pempunyai anggota/unsur yang tidak homogen dan berstrata secara proporsional. Adapun sampel yang digunakan berjumlah 100 orang karyawan atau responden dalam penelitian ini dengan tingkat kesalahan 5\%. (Sugiono, 2012:95-99)

\section{Definisi Konseptual dan Operasional Variabel Pelatihan (Variabel $\mathrm{X}_{1}$ )}

1). Definisi Konseptual

Pelatihan adalah suatu usaha dalam meningkatkan sumber daya manusia dalam dunia usaha. Karyawan baik yang baru maupun yang lama perlu mengikuti pelatihan karena adanya tuntutan pekerjaan yang dapat berubah akibat perubahan lingkungan kerja, strategi dan sebagainya.

2). Definisi Operasional Pelatihan

Operasionalisasi dari penelitian ini adalah dengan mengukur semua indikator menggunakan sekala Likert, dengan 5 jawaban, SS= Sangat Setuju (bobot nilai 5), ST= Setuju (bobot nilai 4), $\mathrm{RG}=$ Ragu-ragu (bobot nilai 3), TS= Tidak Setuju ((bobot nilai 2), STS= Sangat Tidak Setuju (bobot nilai 1)

3). Kisi-kisi kuisioner

\begin{tabular}{|c|l|c|c|l|}
\hline VARIABEL & INDIKATOR & ITEM ANGKET & JUMLAH & ALAT UKUR \\
\hline \multirow{5}{*}{ Pelatihan } & $\begin{array}{l}\text { Penyelenggara } \\
\text { Pelaksana }\end{array}$ & $1,2,3,4,5$ & 5 & \\
\cline { 2 - 4 } & Kebutuhan & $6,7,8,9,10$ & 5 & $\begin{array}{l}\text { Angket yang } \\
\text { menggunakan } \\
\text { skala Likert }\end{array}$ \\
\cline { 2 - 4 } & $\begin{array}{l}\text { Kualitas } \\
\text { Mengajar }\end{array}$ & $11,12,13,14,15$ & 5 & \\
\hline
\end{tabular}

\section{Disiplin Kerja (Variabel $\mathrm{X}_{2}$ )}

1). Definisi Konseptual

Disiplin adalah kepatuhan pada aturan atau perintah yang ditetapkan oleh organisasi. Disiplin merupakan sebuah proses yang digunakan untuk menghadapi permasalahan kinerja dimana proses ini melibatkan pimpinan atau manajer dalam mengidentifikasi dan mengkomunikasikan masalah-masalah kinerja kepada para karyawan.

2). Definisi Operasional Disiplin Kerja

Operasionalisasi dari penelitian ini adalah dengan mengukur semua indikator menggunakan skala Likert, dengan 5 jawaban, SS= Sangat Setuju (bobot nilai 5), ST= Setuju (bobot nilai 4), RG= Ragu-ragu (bobot nilai 3), TS= Tidak Setuju ((bobot nilai 2), STS= Sangat Tidak Setuju (bobot nilai 1)

3). Kisi-kisi kuisioner

\begin{tabular}{|c|l|c|c|c|}
\hline VARIABEL & INDIKATOR & ITEM ANGKET & JUMLAH & ALAT UKUR \\
\hline \multirow{4}{*}{$\begin{array}{c}\text { Disiplin } \\
\text { Kerja }\end{array}$} & $\begin{array}{l}\text { Tujuan dan } \\
\text { Kemampuan }\end{array}$ & $1,2,3$ & 3 & \\
\cline { 2 - 4 } & $\begin{array}{l}\text { Teladan } \\
\text { Pimpinan }\end{array}$ & $4,5,6$ & 3 & \multirow{2}{*}{$\begin{array}{l}\text { Angket yang } \\
\text { menggunakan } \\
\text { skala Likert }\end{array}$} \\
\cline { 2 - 4 } & Balas Jasa & $7,8,9$ & 3 & \multirow{2}{*}{3} \\
\cline { 2 - 4 } & Keadilan & $10,11,12$ & 3 & \\
\cline { 2 - 4 } & $\begin{array}{l}\text { Pengawasan } \\
\text { Melekat }\end{array}$ & $13,14,15$ & 3 & \\
\hline
\end{tabular}

\section{Kinerja Karyawan (Variabel Y)}

1). Definisi Konseptual Kinerja Karyawan

Kinerja adalah hasil kerja secara kualitas dan kuantitas yang dicapai oleh seorang karyawan dalam melaksanakan tugasnya sesuai dengan tanggung jawab yang di berikan kepadanya.

2). Definisi Operasional Kinerja Karyawan Operasionalisasi dari penelitian ini adalah dengan mengukur semua indikator menggunakan sekala Likert, dengan 5 jawaban, 
SS = Sangat Setuju (bobot nilai 5), ST = Setuju (bobot nilai 4), RG= Ragu-ragu (bobot nilai 3), TS= Tidak Setuju ((bobot nilai 2), STS= Sangat Tidak Setuju (bobot nilai 1)

3). Kisi-kisi kuisioner

\begin{tabular}{|c|l|c|c|c|}
\hline VARIABEL & INDIKATOR & ITEM ANGKET & JUMLAH & ALAT UKUR \\
\hline \multirow{4}{*}{$\begin{array}{c}\text { Kinerja } \\
\text { Karyawan }\end{array}$} & $\begin{array}{l}\text { Tanggung- } \\
\text { jawab }\end{array}$ & $1,2,3$ & 3 & \\
\cline { 2 - 4 } & Disiplin & $4,5,6$ & 3 & \multirow{2}{*}{$\begin{array}{c}\text { Angket yang } \\
\text { menggunakan } \\
\text { skala Likert }\end{array}$} \\
\cline { 2 - 4 } & $\begin{array}{l}\text { Pencapaian } \\
\text { Target }\end{array}$ & $7,8,9$ & 3 & \\
\cline { 2 - 4 } & Kejujuran & $10,11,12$ & 3 & \\
\cline { 2 - 4 } & Motivasi & $13,14,15$ & 3 & \\
\hline
\end{tabular}

\section{HASIL dan PEMBAHASAN}

\section{Sejarah Perusahaan}

PT. Surya Mustika Nusantara berdiri pada tahun 2008, PT. Surya Mustika Nusantara adalah Perusahaan yang di miliki oleh PT. Karya Dibya Mahardika untuk menjalankan distribusi produk produk sigaret oleh PT. Karya Dibya Mahardika sebagai produsen, Produk PT. Karya Dibya Mahardika bisa ditemukan dalam berbagai variasi, mulai sigaret kretek klobot (SKL), sigaret kretek linting-tangan (SKT), hingga sigaret kretek linting-mesin (SKM). Untuk produknya yaitu rokok Apache yang mempunyai berbagai variasi pilihan rokok yaitu Apache filter 12, Apache filter 12, Apache kretek 10, Apache kretek 12, Apache kretek 20, Apache Extreme, dan Apache Exotic Menthol. PT. Surya Mustika Nusantara ditunjuk sebagai distributor tunggal yang memegang kendali strategi distribusi dan field marketing untuk seluruh wilayah Indonesia.

Bermarkas di Jakarta, PT. Surya Mustika Nusantara telah tumbuh dan bertransformasi menjadi perusahaan distribusi rokok yang profesional dan modern. Berawal dari beberapa ribu karyawan, kini telah didukung oleh sumber daya manusia mencapai lebih dari 6000 ribu orang yang tersebar pada kantor perwakilan regional dan lebih dari 100 kantor perwakilan area di Indonesia.

\section{Visi Perusahaan}

Visi Perusahaan adalah Menjadi perusahaan besar yang terpandang, menguntungkan dan memiliki peran dominan dalam industri rokok domestik.

\section{Misi Perusahaan}

Misi Perusahaan adalah Menyediakan produk-produk inovatif bermutu tinggi yang memenuhi, bahkan melebihi harapan konsumen sekaligus memberikan manfaat bagi semua Stakeholder.

\section{Uji Asumsi Analisis}

Uji asumsi dasar yang digunakan mengetahui pola dan varian. Apakah populasi atau data berdistribusi normal atau tidak, atau juga uji dapat digunakan untuk mengetahui apakah polulasi mempunyai beberapa varian yang sama. Dalam uji asumsi dasar yang digunakan adalah uji normalitas dan uji homogenitas.

\section{a. Uji Normalitas}

Uji Normalitas digunakan untuk mengetahui apakah populasi data berdistribusi normal atau tidak. Dalam uji normalitas ini yang digunakan uji One Sample Kolmogorov-Smirnov dengan menggunakan taraf signifikansi 0,05. Data dinyatakan berdistribusi normal jika signifikansi lebih besar dari $5 \%$ atau 0,05 . Untuk menguji uji normalitas menggunakan SPSS versi 20.0

1. Pelatihan $\left(\mathrm{X}_{1}\right)$

Uji normalitas merupakan bagian dari uji perasyarat analisis ststistik atau analisis uji asumsi dasar. Uji asumsi dasar adalah syarat yang harus dipenuhi sebelum data yang ada di uji dengan uji ststistik yang sesungguhnya. Hasil pengujian normalitas kinerja karyawan dengan SPSS diperoleh tabel sebagai berikut.

\begin{tabular}{l|l|r|}
\hline \multicolumn{3}{c}{ Tabel 4.1. Hasil Uji Normalitas dengan SPSS Pelatihan $\left(\mathbf{X}_{1}\right)$} \\
\hline \multicolumn{3}{c}{ One-Sample Kolmogorov-Smirnov Test } \\
\hline \multicolumn{2}{|c|}{} & $\begin{array}{c}\text { Unstandardized } \\
\text { Residual }\end{array}$ \\
\hline $\mathrm{N}$ & & 100 \\
\hline \multirow{4}{*}{ Normal Parameters ${ }^{\text {ab }}$} & Mean & $0 \mathrm{E}-7$ \\
\cline { 2 - 3 } & Std. Deviation & 3.50658041 \\
\cline { 2 - 3 } & Absolute & .097 \\
\hline Most Extreme Differences & Positive & .051 \\
\hline & Negative & .097 \\
\hline Kolmogorov-Smirnov Z & & .973 \\
\hline Asymp. Sig. (2-tailed) & & .300 \\
\hline
\end{tabular}

Berdasarkan tabel output SPSS tersebut, diketahui bahwa nilai signifikansi Asymp.Sig 
(2-tailed) 0,300 lebih besar dari 0,05. Maka sesuai dengan pengambilan keputusan dalam uji normalitas kolmogrov-smirnov diatas, dapat disimpulkan bahwa data berdistribusi normal. Dengan demikian, asumsi atau persyarat normalitas dalam model regresi sudah terpenuhi.

2. Disiplin Kerja $\left(\mathrm{X}_{2}\right)$

Uji normalitas merupakan bagian dari uji perasyarat analisis ststistik atau analisis uji asumsi dasar. Uji asumsi dasar adalah syarat yang harus dipenuhi sebelum data yang ada di uji dengan uji ststistik yang sesungguhnya. Hasil pengujian normalitas kinerja karyawan dengan SPSS diperoleh tabel sebagai berikut.

\begin{tabular}{|c|c|c|}
\hline \multicolumn{3}{|c|}{ One-Sample Kolmogorov-Smirnov Test } \\
\hline & & $\begin{array}{l}\text { Unstandardized } \\
\text { Residual }\end{array}$ \\
\hline $\mathrm{N}$ & & 100 \\
\hline \multirow{3}{*}{ Normal Parameters ${ }^{\mathrm{a}, \mathrm{b}}$} & Mean & $0 \mathrm{E}-7$ \\
\hline & Std. Deviation & 3.35155101 \\
\hline & Absolute & .049 \\
\hline \multirow[t]{2}{*}{ Most Extreme Differences } & Positive & .042 \\
\hline & Negative & -.049 \\
\hline Kolmogorov-Smirnov Z & & .495 \\
\hline Asymp. Sig. (2-tailed) & & .967 \\
\hline
\end{tabular}

Berdasarkan tabel output SPSS tersebut, diketahui bahwa nilai signifikansi Asymp.Sig (2-tailed) 0,967 lebih besar dari 0,05. Maka sesuai dengan pengambilan keputusan dalam uji normalitas kolmogrov-smirnov diatas, dapat disimpulkan bahwa data berdistribusi normal. Dengan demikian, asumsi atau persyarat normalitas dalam model regresi sudah terpenuhi.

3. Kinerja Karyawan (Y)

Uji normalitas merupakan bagian dari uji perasyarat analisis ststistik atau analisis uji asumsi dasar. Uji asumsi dasar adalah syarat yang harus dipenuhi sebelum data yang ada di uji dengan uji ststistik yang sesungguhnya. Hasil pengujian normalitas kinerja karyawan dengan SPSS diperoleh tabel sebagai berikut.

Berdasarkan tabel output SPSS tersebut, diketahui bahwa nilai signifikansi Asymp.Sig (2-tailed) 0,829 lebih besar dari 0,05. Maka sesuai dengan pengambilan keputusan dalam uji normalitas kolmogrov-smirnov diatas, dapat disimpulkan bahwa data berdistribusi normal. Dengan demikian, asumsi atau persyarat normalitas dalam model regresi sudah terpenuhi.

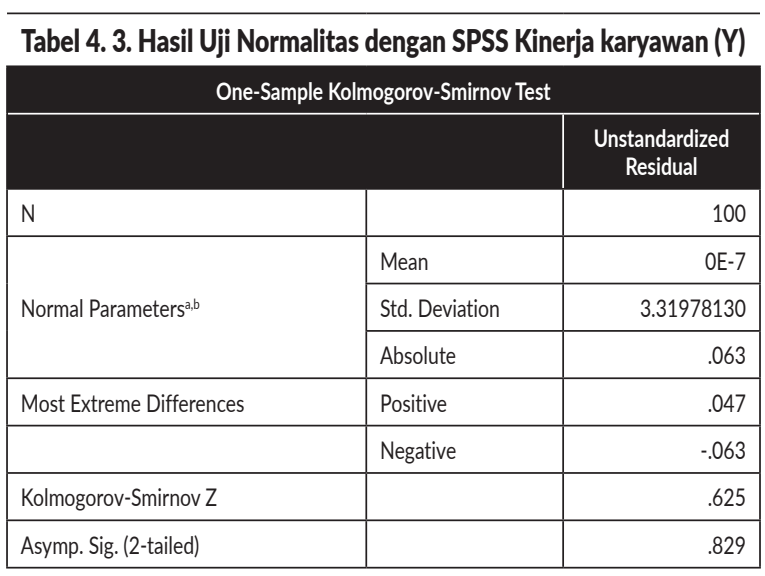

\section{Uji Homogenitas}

Uji homogenitas dimaksudkan untuk memperlihatkan bahwa dua atau lebih kelompok data sampel berasal dari populasi yang memiliki variansi yang sama.

Teknik pengujian yang digunakan adalah uji bartlet. Uji bartlet dilakukan dengan menghitung $\mathrm{x}^{2}$. Harga $\mathrm{x}^{2}$ yang diperoleh dari perhitungan $\left(\mathrm{x}^{2}\right.$ hitung), selanjutnya dibandingkan dengan $\mathrm{x} 2$ tabel ( $\mathrm{X}^{2}$ tabel), bila $\mathrm{x}^{2}$ hitung $<\mathrm{x}^{2}$ tabel, maka hipotesis nol diteima. Artinya data berasal dari populasi yang homogen. Perhitungan uji homogenitas ini dengan menggunakan software SPSS versi 20.

\begin{tabular}{|c|c|c|c|}
\hline \multicolumn{4}{|c|}{$\begin{array}{c}\text { Tabel 4. 4. Uji Homogenitas Variabel Kinerja Karyawan }(Y) \\
\text { Dengan Variabel Pelatihan }\left(X_{1}\right)\end{array}$} \\
\hline \multicolumn{4}{|c|}{ Test of Homogeneity of Variances } \\
\hline \multicolumn{4}{|l|}{ Kinerja Karyawan } \\
\hline Levene Statistic & df1 & df2 & Sig. \\
\hline .735 & 16 & 80 & .751 \\
\hline
\end{tabular}

Dari tabel Test of Homogeneity of Variances dapat diketahui kedua variabel antara kinerja karyawan dengan variable tata pelatihan terlihat signifikasi sebesar 0,751 . Nilai ini menunjukkan bahwa nilai sig $>a=0,751>0,05$ maka dapat disimpulkan kedua kelompok data mempunyai varian yang sama. 


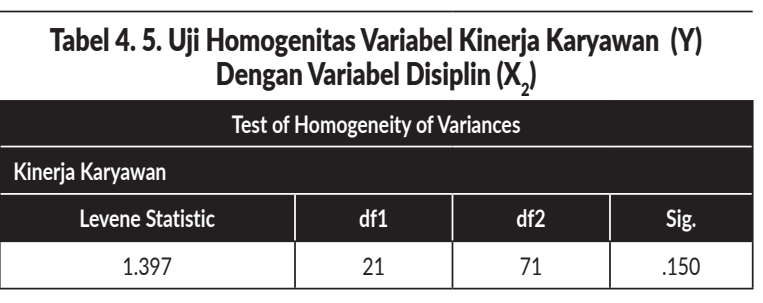

Dari tabel Test of Homogeneity of Variances dapat diketahui kedua variabel antara kinerja karyawan dengan variable Disiplin kerja terlihat signifikasi sebesar 0,150 . Nilai ini menunjukkan bahwa nilai sig $>a=0,150>0,05$ maka dapat disimpulkan kedua kelompok data mempunyai varian yang sama.

\section{Pengujian Hipotesis}

Setelah dilakukan pengujian instrument (uji validitas, uji reliabilitas dan uji asumsi statisik), di atas maka langkah selanjutnya pengujian hipotesis, yaitu utuk mengetahui pengaruh antara kedua variable independen terhadap satu variable dependen yang dikemukakan dalam rumusan masalah. Sesuai dengan tahapan-tahapan pada metode penelitian Bab III, maka data primer yang telah ditabulasi dan diolah dengan menggunakan analisa Program SPSS 20, peneliti uraikan hasilnya sebagai berikut:

1. Pengaruh Pelatihan $\left(\mathrm{X}_{1}\right)$ Terhadap Kinerja Karyawan (Y)

Hasil penelitian Pengaruh Pelatihan $\left(\mathrm{X}_{1}\right)$ Terhadap Kinerja karyawan $(\mathrm{Y})$, setelah melalui tahapan pengujian statistik dengan dengan olah data SPSS 20 hasilnya dapat dideskripsikan lebih rinci sebagai berikut:

a. Uji Korelasi Sederhana

\begin{tabular}{|c|c|c|c|}
\hline \multicolumn{4}{|c|}{ Tabel 4.6. Hasil Uji $r_{\text {hitung }}$ Variabel $X_{1}$ Terhadap VariabelY } \\
\hline \multicolumn{4}{|c|}{ Correlations } \\
\hline & & $\begin{array}{c}\text { Kinerja } \\
\text { Karyawan }\end{array}$ & Pelatihan \\
\hline \multirow{3}{*}{ Kinerja Karyawan } & Pearson Correlation & 1 & .113 \\
\hline & Sig. (2-tailed) & & .264 \\
\hline & $\mathrm{N}$ & 100 & 100 \\
\hline \multirow{3}{*}{ Pelatihan } & Pearson Correlation & .113 & 1 \\
\hline & Sig. (2-tailed) & .264 & \\
\hline & $\mathrm{N}$ & 100 & 100 \\
\hline
\end{tabular}

Data pada tabel di atas, menunjukkan skor nilai korelasi sebesar 0,113. Hasil ini menunjukkan adanya pe- ngaruh yang positif dan signifikan antara Pelatihan $\left(\mathrm{X}_{1}\right)$ Terhadap Kinerja karyawan (Y). Untuk mengetahui apakah korelasi tersebut dapat digeneralisasikan atau tidak, maka perlu dibandingkan dengan nilai $\mathrm{r}_{\text {tabel }}$ dengan taraf kesalahan 5\% (derajat kepercayaan 95\%). Untuk harga $n=100$ pada tabel nilai-nilai $r$ product moment menunjukkan skor nilai $\mathrm{r}_{\text {tabel }}$ sebesar 0,195. Ternyata harga $\mathrm{r}_{\text {hitung }}$ $(0,113)<$ harga $r_{\text {tabel }}(0,195)$, sehingga $\mathrm{H}_{0}$ diterima dan $\mathrm{H}_{\mathrm{a}}$ ditolak. Jadi kesimpulannya ada pengaruh positif dan signifikan antara Pelatihan $\left(\mathrm{X}_{1}\right)$ Terhadap Kinerja karyawan (Y).

b. Uji Hipotesis $\left(\mathrm{t}_{\text {hitung }}\right)$

Hasil pengolahan data statistik $t$ hitung pada ini dapat dilihat pada tabel 4.7 di bawah ini

\begin{tabular}{|c|c|c|c|c|c|c|}
\hline & & & One-Sam & Test & & \\
\hline & & & & t Value = 58 & & \\
\hline & $\mathrm{t}$ & $\mathrm{df}$ & Sig. & Mean & $\begin{array}{l}95 \% \text { Confide } \\
\text { the Dif }\end{array}$ & $\begin{array}{l}\text { Interval of } \\
\text { ance }\end{array}$ \\
\hline & & & & & Lower & Upper \\
\hline Pelatihan $\left(X_{1}\right)$ & 1.984 & 99 & .152 & .720 & -.27 & 1.71 \\
\hline Kinerja $(Y)$ & 1.443 & 99 & .050 & .700 & .00 & 1.40 \\
\hline
\end{tabular}

Sebelum mengambil keputusan, pertam-tama kita membuat sebagai berikut :

$\mathrm{H}_{0}$ : Hasil pelatihan rata-rata adalah 58

$\mathrm{H}_{\mathrm{i}}$ : Hasil pelatihan rata-rata tidak sama dengan 58

Syarat $\mathrm{H}_{0}$ diterima atau tidak berdasarkan nilai probabilitas sebagai berikut :

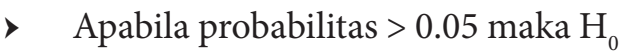
diterima

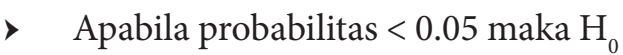
ditolak

Dari hasil di atas pada kolom Sig terlihat bahwa nilai probabilitas 0.152 .

Maka $\mathrm{H}_{0}$ ditolak $(0.152<0.05)$. Dengan demikian keputusan yang diambil adalah

Jadi : rata-rata hasil pelatihan tidak 
sama dengan 58 .

c. Uji Regresi Linier

Analisis regresi dibuat untuk mengetahui antara variable indevenden dengan variable dependen. Dalam pengujian hipotesis ke - 1 hasil uji regresi liniernya dapat dilihat pada tabel $4.8 \mathrm{di}$ bawah ini.

\begin{tabular}{|c|c|c|c|c|c|}
\hline \multicolumn{6}{|c|}{ Coefficients $^{\mathrm{a}}$} \\
\hline \multirow[b]{2}{*}{ Model } & \multicolumn{2}{|c|}{$\begin{array}{l}\text { Unstandardized } \\
\text { Coefficients }\end{array}$} & \multicolumn{3}{|c|}{ Standardized Coefficients } \\
\hline & B & Std. Error & Beta & $t$ & Sig. \\
\hline 1 (Constant) & 54.015 & 4.184 & & 12.910 & .000 \\
\hline Pelatihan & .080 & .071 & .113 & 1.124 & .264 \\
\hline
\end{tabular}

Pada tabel di atas, menunjukkan hasil perhitungan regresi linier sederhana nilai koefesien a dan $\mathrm{b}$ sebagai berikut : $\hat{Y}=54.015+0.080 . X$

Persamaan regresi yang digunakan untuk melakukan prediksi (ramalan) dalam variable dependen akan terjadi bila dalam variable indevenden ditetapkan. Jadi bila Pelatihan $\left(\mathrm{X}_{1}\right)$ meningkat/ ditingkatkan hingga mendapat nilai 1, maka Kinerja karyawan (Y) menjadi : $\hat{Y}$ $=54.015+0.080 .1=55.095$

Jadi diperkirakan Kinerja karyawan akan meningkat sebesar 55.095. Dengan demikian, Kinerja karyawan akan naik, bila Pelatihan lebih meningkat. Hal ini membuktikan bahwa variable indevenden $\mathrm{X}_{1}$ (Pelatihan) searah terhadap naiknya turunnya $v a$ riable dependent Y (Kinerja karyawan).

2. Pengaruh Disiplin $\left(\mathrm{X}_{2}\right)$ Terhadap Kinerja Karyawan (Y)

Hasil penelitian Pengaruh Disiplin $\left(\mathrm{X}_{2}\right)$ Terhadap Kinerja karyawan (Y), setelah melalui tahapan pengujian statistik dengan dengan olah data SPSS 20 hasilnya dapat dideskripsikan lebih rinci sebagai berikut:

\section{a. Uji Korelasi Sederhana}

Analisis selanjutnya dilakukan dengan cara yang sama seperti pada pengujian hipotesis ke-2. Melalui tahapan pengujian statistik, maka Pengaruh Disiplin Terhadap Kinerja Karyawan akan Nampak pada tabel di bawah ini:

\begin{tabular}{|c|c|c|c|}
\hline \multicolumn{4}{|c|}{$\begin{array}{r}\text { Tabel 4.9. Hasil Uji } r_{\text {hitung }} \text { Variabel X } \\
\text { Correlations }\end{array}$} \\
\hline & & Kinerja & Disiplin \\
\hline \multirow{3}{*}{ Kinerja } & Pearson Correlation & 1 & $.313^{* *}$ \\
\hline & Sig. (2-tailed) & & .002 \\
\hline & $\mathrm{N}$ & 100 & 100 \\
\hline \multirow{3}{*}{ Disiplin } & Pearson Correlation & $.313^{* *}$ & 1 \\
\hline & Sig. (2-tailed) & .002 & \\
\hline & $\mathrm{N}$ & 100 & 100 \\
\hline
\end{tabular}

Data pada tabel di atas, menunjukkan skor nilai korelasi sebesar 0,313. Hasil ini menunjukkan adanya pengaruh yang positif dan signifikan antara Disiplin $\left(\mathrm{X}_{2}\right)$ Terhadap Kinerja karyawan (Y). Untuk mengetahui apakah korelasi tersebut dapat digeneralisasikan atau tidak, maka perlu dibandingkan dengan nilai $\mathrm{r}_{\text {tabel }}$ dengan taraf kesalahan 5\% (derajat kepercayaan 95\%). Untuk harga $\mathrm{n}=100$ pada tabel nilai-nilai $\mathrm{r}$ product moment menunjukkan skor nilai $\mathrm{r}_{\text {tabel }}$ sebesar 0,176. Ternyata harga $r_{\text {hitung }}$ $(0,313)>$ harga $r_{\text {tabel }}(0,176)$, sehingga $\mathrm{H}_{0}$ ditolak dan $\mathrm{H}_{\mathrm{a}}$ diterima. Jadi kesimpulannya ada pengaruh positif dan signifikan antara Displin $\left(\mathrm{X}_{2}\right)$ Terhadap Kinerja karyawan (Y).

b. Uji Hipotesis $\left(\mathrm{t}_{\text {hitung }}\right)$

Hasil pengolahan data statistik $\mathrm{t}_{\text {hitung }}$ pada ini dapat dilihat pada tabel $4.10 \mathrm{di}$ bawah ini:

\begin{tabular}{|c|c|c|c|c|c|c|}
\hline \multicolumn{7}{|c|}{$\begin{array}{r}\text { Tabel 4.10. Hasil Uji t }{ }_{\text {hitung }} \text { Variabel } \mathbf{X}_{2} \\
\text { One-Sample Test }\end{array}$} \\
\hline & \multicolumn{6}{|c|}{ Test Value $=55$} \\
\hline & \multirow{2}{*}{$t$} & \multirow{2}{*}{ df } & \multirow{2}{*}{$\begin{array}{c}\text { Sig. } \\
\text { (2-tailed) }\end{array}$} & \multirow{2}{*}{$\begin{array}{c}\text { Mean } \\
\text { Difference }\end{array}$} & \multicolumn{2}{|c|}{$\begin{array}{l}95 \% \text { Confidence Interval of } \\
\text { the Difference }\end{array}$} \\
\hline & & & & & Lower & Upper \\
\hline Disiplin $\left(X_{2}\right)$ & .610 & 99 & .543 & .540 & -1.22 & 2.30 \\
\hline Kinerja $(Y)$ & 10.484 & 99 & .000 & 3.700 & 3.00 & 4.40 \\
\hline
\end{tabular}

Sebelum mengambil keputusan, pertam-tama kita membuat sebagai berikut :

$\mathrm{H}_{0}$ : Tingkat Disiplin rata-rata adalah 
55

$\mathrm{H}_{\mathrm{i}}$ : Tingkat Disiplin rata-rata tidak sama dengan 55

Syarat $\mathrm{H}_{0}$ diterima atau tidak berdasarkan nilai probabilitas sebagai berikut :

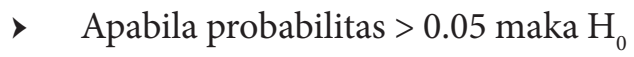
diterima.

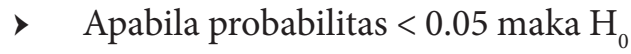
ditolak.

Dari hasil di atas pada kolom Sig terlihat bahwa nilai probabilitas 0.543 .

Maka $\mathrm{H}_{0}$ ditolak $(0.543<0.05)$. Dengan demikian keputusan yang diambil adalah

Jadi : rata-rata tingkat disipin tidak sama dengan 55 .

c. Uji Regresi Linier

Analisis regresi dibuat untuk mengetahui antara variable indevenden dengan variable dependen. Dalam pengujian hipotesis ke - 1 hasil uji regresi liniernya dapat dilihat pada tabel $4.11 \mathrm{di}$ bawah ini.

\begin{tabular}{|c|c|c|c|c|c|}
\hline \multicolumn{6}{|c|}{ Tabel 4.11. Hasil Uji Regresi Linier Variabel $X_{2}$ Terhadap VariabelY } \\
\hline \multicolumn{6}{|c|}{ Coefficients $^{\mathrm{a}}$} \\
\hline \multirow[b]{2}{*}{ Model } & \multicolumn{2}{|c|}{$\begin{array}{l}\text { Unstandardized } \\
\text { Coefficients }\end{array}$} & \multicolumn{3}{|c|}{ Standardized Coefficients } \\
\hline & B & Std. Error & Beta & $\mathrm{t}$ & Sig. \\
\hline 1 (Constant) & 51.769 & 2.149 & & 24.085 & .000 \\
\hline Disiplin & .125 & . 038 & .313 & 3.265 & .002 \\
\hline a. [ & & & & & \\
\hline
\end{tabular}

Pada tabel di atas, menunjukkan hasil perhitungan regresi linier sederhana nilai koefesien a dan b sebagai berikut : $\hat{Y}=51.769+0.125 . X$

Persamaan regresi yang digunakan untuk melakukan prediksi (ramalan) dalam variable dependen akan terjadi bila dalam variable indevenden ditetapkan. Jadi bila Disiplin $\left(\mathrm{X}_{2}\right)$ meningkat/ ditingkatkan hingga mendapat nilai 1 , maka Kinerja karyawan (Y) menjadi $: \hat{Y}=51.769+0.125 .1=52.894$. Jadi diperkirakan Kinerja karyawan akan meningkat sebesar 52.894. Dengan demikian, Kinerja karyawan akan naik, bila Pelatihan lebih meningkat. Hal ini membuktikan bahwa variable indevenden $\mathrm{X}_{2}$ (Disiplin) searah terhadap naiknya turunnya variable dependent $\mathrm{Y}$ (Kinerja karyawan).

3. Pengaruh Pelatihan $\left(\mathrm{X}_{1}\right)$ dan Disiplin $\left(\mathrm{X}_{2}\right)$ Terhadap Kinerja Karyawan (Y)

a. Uji Korelasi Berganda

Setelah data ketiga variable dirangkum dalam tabel tabulasi dan dianalisis melalui hasil uji korelasi berganda, maka pengujian hipotesis ke-3 ini hasilnya dapat dilihat pada tabel 4.12

\begin{tabular}{|c|c|c|c|c|}
\hline \multicolumn{5}{|c|}{$\begin{array}{c}\text { Tabel 4.12. Hasil Uji Korelasi Berganda } \\
\text { Variabel } X_{1} \text { Variabel X Terhadap Variabel Y }\end{array}$} \\
\hline \multicolumn{5}{|c|}{ Correlations } \\
\hline & & $\begin{array}{c}\text { Kinerja } \\
\text { Karyawan }\end{array}$ & Pelatihan & $\begin{array}{l}\text { Disiplin } \\
\text { Kerja }\end{array}$ \\
\hline \multirow{3}{*}{$\begin{array}{l}\text { Kinerja } \\
\text { Karyawan }\end{array}$} & Pearson Correlation & 1 & .113 & $.313^{* *}$ \\
\hline & Sig. (2-tailed) & & .264 & .002 \\
\hline & $N$ & 100 & 100 & 100 \\
\hline \multirow{3}{*}{ Pelatihan } & Pearson Correlation & .113 & 1 & -.056 \\
\hline & Sig. (2-tailed) & .264 & & .582 \\
\hline & $\mathrm{N}$ & 100 & 100 & 100 \\
\hline \multirow{3}{*}{$\begin{array}{l}\text { Disiplin } \\
\text { Kerja }\end{array}$} & Pearson Correlation & $.313^{* *}$ & -.056 & 1 \\
\hline & Sig. (2-tailed) & .002 & .582 & \\
\hline & $\mathrm{N}$ & 100 & 100 & 100 \\
\hline
\end{tabular}

Berdasarkan tabel output di atas, maka akan disimpulkan:

1. Berdasarkan nilai sig. (2-tailed) antara Pelatihan $\left(\mathrm{X}_{1}\right)$ dengan Kinerja karyawan $(\mathrm{Y})$ adalah sebesar $0,002<0,05$ yang berarti terdapat korelasi yang signifikan antara variable pelatihan dengan variable kinerja karyawan. Selanjutnya hubungan antara Disiplin dengan Kinerja karyawan memiliki nilai sig. (2 tailed) sebesar 0,528 $<0,05$ yang berarti terdapat korelasi yang signifikan antara variable disiplin dengan kinerja karyawan.

2. Berdasarkan nilai $\mathrm{r}_{\text {hitung }}$ (Person Correlation)

Diketahui $\mathrm{r}_{\text {hitung }}$ untuk hubungan pelatihan $\left(\mathrm{X}_{1}\right)$ dengan kinerja karyawan (Y) adalah sebesar 
$0,313>$ dari $\mathrm{r}_{\text {tabel }} 0,195$. Maka dapat disimpulkan bahwa ada hubungan atau korelasi antara variable Disiplin dengan Kinerja karyawan. selanjutnya diketahui nilai $r_{\text {hitung }}$ untuk hubungan disiplin $\left(\mathrm{X}_{2}\right)$ dengan kinerja karyawan (Y) adalah sebesar $-0,056<$ dari $\mathrm{r}_{\text {tabel }} 0,195$, maka dapat disimpulkan bahwa ada hubungan korelasi antara variable disiplin dengan variable kinerja pegawai. Karena $r_{\text {hitung }}$ atau person correlation dalam analisis bernilai negatif maka hubungan kedua variable tersebut bersifat negatif. Semakin meningkatnya pelatihan dan disiplin maka akan semakin meningkat juga kinerja karyawan.

b. $\quad \mathrm{Uji}_{\text {hitung }}$ (T-Test)

Pada uji F ini akan ditampilkan tabel analisis varian anova. Uji anova yaitu untuk mengetahui ada tidaknya hubungan dari ketiga variable. Oleh karena itu untuk mengetahui apakah koefesien korelasi berganda di atas dapat digeneralisasikan atau tidak, maka harus diuji signifikan dengan Uji $\mathrm{F}_{\text {hitung. }}$. Untuk mengetahui hasil $\mathrm{F}_{\text {hitung }}$ (Anova) dapat dilihat pada tabel 4.13 di bawah ini:

\begin{tabular}{|c|c|c|c|c|c|c|}
\hline \multicolumn{7}{|c|}{$\begin{array}{l}\text { Tabel 4.13. Hasil Uji } F_{\text {hitung }} \text { Variabel } X_{1} \text { Variabel } X_{2} \\
\text { Terhadap Variabel } Y\end{array}$} \\
\hline \multicolumn{7}{|c|}{ ANOVA $^{2}$} \\
\hline \multicolumn{2}{|c|}{ Model } & $\begin{array}{l}\text { Sum of } \\
\text { Squares }\end{array}$ & df & $\begin{array}{l}\text { Mean } \\
\text { Square }\end{array}$ & $\mathrm{F}$ & Sig. \\
\hline 1 & Regression & 141.926 & 2 & 70.963 & 6.309 & $.003^{b}$ \\
\hline & Residual & 1091.074 & 97 & 11.248 & & \\
\hline & Total & 1233.000 & 99 & & & \\
\hline $\begin{array}{l}\text { a. De } \\
\text { b. } \operatorname{Pr}\end{array}$ & s: (Const & $\begin{array}{l}\text { Karyaw } \\
n\left(X_{2}\right), P\end{array}$ & & & & \\
\hline
\end{tabular}

Dari tabel 4.13, menunjukkan hasil uji $\mathrm{F}_{\text {hitung }}$ dengan analisis program SPSS versi 20 , yakni $\mathrm{F}_{\text {hitung }}$ diperoleh skor nilai sebesar 6.309. Harga ini selanjutnya perlu dikonsultasikan dengan $\mathrm{F}_{\text {tabel }}$ dengan $\mathrm{dk}$ pembilang $=\mathrm{k}$ dan $\mathrm{dk}$ penyebut $=(\mathrm{n}-\mathrm{k}-1)$ dengan taraf kesalahan yang ditetapkan $5 \%(\alpha=0,05)$ untuk $n=100$ adalah 1.39 . Jadi $\mathrm{F}_{\text {hitung }}(6.309)>\mathrm{F}_{\text {tabel }}$ (1.39), maka dapat dinyatakan bahwa Pelatihan $\left(\mathrm{X}_{1}\right)$ dan Disiplin Kerja $\left(\mathrm{X}_{2}\right)$ secara bersamasama berpengaruh terhadap Kinerja karyawan $(\mathrm{Y})$.

Dengan demikian, rumusan hipotesis ketiga yang dinyatakan sebelumya “Terdapat pengaruh yang positif dan signifikan Pelatihan $\left(\mathrm{X}_{1}\right)$ dan Disiplin Kerja $\left(\mathrm{X}_{2}\right)$ secara bersama-sama berpengaruh terhadap Kinerja karyawan (Y) pada PT Surya Mustika Nusantara", terbukti kebenarannya.

c. Uji Regresi Linier Berganda

Pada korelasi ganda dapat dilanjutkan denga regresi ganda. Regresi linier berganda atau regresi multiplelinier memiliki perbedaan pada variable bebas, yaitu dalam kaitan ini memiliki dua variable bebas (atau lebih). Pada bagian ini ditampilkan tabel koefesien regresi berganda yang diolah dari data interval atau rasio gabungan dari ketiga variabel, yaitu sebagai berikut:

\begin{tabular}{|c|c|c|c|c|c|}
\hline \multicolumn{6}{|c|}{$\begin{array}{c}\text { Tabel 4.14. Hasil Uji Regresi Berganda } \\
\text { Variabel } X_{1} \text { Variabel } X_{2} \text { Terhadap VariabelY }\end{array}$} \\
\hline \multicolumn{6}{|c|}{ Coefficients $^{a}$} \\
\hline \multirow[b]{2}{*}{ Model } & \multicolumn{2}{|c|}{$\begin{array}{l}\text { Unstandardized } \\
\text { Coefficients }\end{array}$} & \multicolumn{3}{|c|}{ Standardized Coefficients } \\
\hline & B & Std. Error & Beta & $t$ & Sig. \\
\hline 1 (Constant) & 46.181 & 4.617 & & 10.002 & .000 \\
\hline Pelatihan $\left(X_{1}\right)$ & .092 & .068 & .131 & 1.366 & .175 \\
\hline Disiplin $\left(X_{2}\right)$ & .128 & .038 & .320 & 3.350 & .001 \\
\hline
\end{tabular}

Berdasarkan perhitungan yang telah ditemukan melaui analisis data pada tabel di atas, diketahui nilai konstanta a dan koefesien b yang ditunjukkan pada perhitungan regresi linier berganda di atas dapat dihitung ke dalam rumus sebagai berikut:

$\hat{\mathrm{Y}}=46.181+0.092 .\left(\mathrm{X}_{1}\right)+0.182 .\left(\mathrm{X}_{2}\right)$

Diketahui nilai konstanta 46.181 . Ini berarti pada Pelatihan dan Disiplin kerja lebih meningkat maka Kinerja karyawan pun akan bertambah. koefesien regresi untuk Pelatihan (0.092) lebih kecil daripada koefesien regresi untuk Disiplin kerja (0.128). Jadi bila 
Pelatihan dan Disiplin kerja lebih meningkat, maka kinerja karyawan menjadi :

$$
\begin{aligned}
\hat{Y} & =46.181+0.092 .(1)+0.182 .(1) \\
& =46.181+0.092+0.182=46.455
\end{aligned}
$$

Hal tersebut, memberikan gambaran bahwa arah hubungan antara Pelatihan dan Disiplin kerja ternyata searah, dimana setiap kenaikan satu satuan pada variable bebas (Pelatihan dan Disiplin kerja) akan menyebabkan kenaikan terhadap variable terikat (Kinerja karyawan) sebesar 46.455 Artinya bila Pelatihan dan Disiplin kerja dapat dioptimalkan/ditingkatkan lebih baik, maka kinerja karyawan PT Surya Mustika Nusantara lebih bertambah meningkat.

\section{Pembahasan Hasil Penelitian}

Berdasarkan hasil penelitian dan analisis data Pelatihan $\left(\mathrm{X}_{1}\right)$ dan Disiplin kerja $\left(\mathrm{X}_{2}\right)$ Terhadap Kinerja karyawan (Y) di PT Surya Mustika Nusantara melalui tahapan uji hipotesis yang telah diuraikan di atas, maka pembahasan sebagai berikut:

Pengujian hipotesis ke 1 Pengaruh Pelatihan $\left(\mathrm{X}_{1}\right)$ Terhadap Kinerja karyawan $(\mathrm{Y})$ Hasil uji korelasi menunjukkan adanya pengaruh yang positif dan signifikan antara Pelatihan $\left(\mathrm{X}_{1}\right)$ Terhadap Kinerja karyawan (Y). Untuk mengetahui apakah korelasi tersebut dapat digeneralisasikan atau tidak, maka perlu dibandingkan dengan nilai $\mathrm{r}_{\text {tabel }}$ dengan taraf kesalahan 5\% (derajat kepercayaan 95\%). Untuk harga $\mathrm{n}=100$ pada tabel nilai-nilai $\mathrm{r}$ product moment menunjukkan skor nilai $\mathrm{r}_{\text {tabel }}$ sebesar 0,195 . Ternyata harga $r_{\text {hitung }}(0,113)<$ harga $r_{\text {tabel }}$ $(0,195)$, sehingga $\mathrm{H}_{0}$ diterima dan $\mathrm{H}_{\mathrm{a}}$ ditolak. Jadi kesimpulannya ada pengaruh positif dan signifikan antara Pelatihan $\left(\mathrm{X}_{1}\right)$ Terhadap Kinerja karyawan (Y). Dari hasil uji t pada kolom Sig terlihat bahwa nilai probabilitas 0.152 . Maka $\mathrm{H}_{0}$ ditolak $(0.152<0.05)$. Dengan demikian keputusan yang diambil adalah rata-rata hasil pelatihan tidak sama dengan 58 . Persamaan regresi yang digunakan untuk melakukan pre- diksi (ramalan) dalam variable dependen akan terjadi bila dalam variable indevenden ditetapkan. Jadi bila Pelatihan $\left(\mathrm{X}_{1}\right)$ meningkat/ ditingkatkan hingga mendapat nilai 1, maka Kinerja karyawan $(\mathrm{Y})$ menjadi : $\hat{\mathrm{Y}}=54.015+0.080 .1=$ 55.095 Jadi diperkirakan Kinerja karyawan akan meningkat sebesar 55.095. Dengan demikian, Kinerja karyawan akan naik, bila Pelatihan lebih meningkat. Hal ini membuktikan bahwa variable indevenden X1 (Pelatihan) searah terhadap naiknya turunnya variable dependent $\mathrm{Y}$ (Kinerja karyawan).

Pengujian hipotesis ke 2 Pengaruh Disiplin $\left(\mathrm{X}_{2}\right)$ Terhadap Kinerja karyawan $(\mathrm{Y})$ menunjukkan adanya pengaruh yang positif dan signifikan antara Disiplin $\left(\mathrm{X}_{2}\right)$ Terhadap Kinerja karyawan (Y). Untuk mengetahui apakah korelasi tersebut dapat digeneralisasikan atau tidak, maka perlu dibandingkan dengan nilai $\mathrm{r}_{\text {tabel }}$ dengan taraf kesalahan 5\% (derajat kepercayaan 95\%). Untuk harga $\mathrm{n}=100$ pada tabel nilainilai $\mathrm{r}$ product moment menunjukkan skor nilai $\mathrm{r}_{\text {tabel }}$ sebesar 0,176. Ternyata harga $\mathrm{r}_{\text {hitung }}(0,313)$ $>$ harga $r_{\text {tabel }}(0,176)$, sehingga $H_{0}$ ditolak dan $\mathrm{H}_{\mathrm{a}}$ diterima. Jadi kesimpulannya ada pengaruh positif dan signifikan antara Displin $\left(\mathrm{X}_{2}\right)$ Terhadap Kinerja karyawan (Y). Dari hasil uji $t$ pada kolom Sig terlihat bahwa nilai probabilitas 0.543. Maka $\mathrm{H}_{0}$ ditolak $(0.543<0.05)$. Dengan demikian keputusan yang diambil adalah Jadi : rata-rata tingkat disipin tidak sama dengan 55. hasil perhitungan regresi linier sederhana nilai koefesien a dan b sebagai berikut : $\hat{Y}=51.769+$ 0.125 . X

Persamaan regresi yang digunakan untuk melakukan prediksi (ramalan) dalam variable dependen akan terjadi bila dalam variable indevenden ditetapkan. Jadi bila Disiplin $\left(\mathrm{X}_{2}\right)$ meningkat/ditingkatkan hingga mendapat nilai 1, maka Kinerja karyawan $(\mathrm{Y})$ menjadi $: \hat{\mathrm{Y}}=51.769$ $+0.125 .1=52.894$. Jadi diperkirakan Kinerja karyawan akan meningkat sebesar 52.894. Dengan demikian, Kinerja karyawan akan naik, bila Pelatihan lebih meningkat. Hal ini membuktikan bahwa variable indevenden $\mathrm{X}_{2}$ (Disiplin) searah terhadap naiknya turunnya variable dependent $\mathrm{Y}$ (Kinerja karyawan). 
Pengujian hipotesis ke 3 Pengaruh Pelatihan $\left(\mathrm{X}_{1}\right)$ dan Disiplin $\left(\mathrm{X}_{2}\right)$ Terhadap Kinerja karyawan (Y) pengujian korelasi berganda menunjukkan bahwa nilai sig. (2-tailed) antara Pelatihan $\left(\mathrm{X}_{1}\right)$ dengan Kinerja karyawan $(\mathrm{Y})$ adalah sebesar 0,002 $<0,05$ yang berarti terdapat korelasi yang signifikan antara variable pelatihan dengan variable kinerja karyawan. Selanjutnya hubungan antara Disiplin dengan Kinerja karyawan memiliki nilai sig. (2 tailed) sebesar 0,528 $<0,05$ yang berarti terdapat korelasi yang signifikan antara variable disiplin dengan kinerja karyawan. hasil uji $\mathrm{F}_{\text {hitung }}$ dengan analisis program SPSS versi 20, yakni $\mathrm{F}_{\text {hitung }}$ diperoleh skor nilai sebesar 6.309. Harga ini selanjutnya perlu dikonsultasikan dengan $\mathrm{F}_{\text {tabel }}$ dengan $\mathrm{dk}$ pembilang $=\mathrm{k}$ dan $\mathrm{dk}$ penyebut $=(\mathrm{n}-\mathrm{k}-1)$ dengan taraf kesalahan yang ditetapkan 5\% $(\alpha=0,05)$ untuk $\mathrm{n}=100$ adalah 1.39. Jadi $\mathrm{F}_{\text {hitung }}(6.309)>\mathrm{F}_{\text {tabel }}$ (1.39), maka dapat dinyatakan bahwa Pelatihan $\left(\mathrm{X}_{1}\right)$ dan Disiplin Kerja $\left(\mathrm{X}_{2}\right)$ secara bersama-sama berpengaruh terhadap Kinerja karyawan (Y).

Dengan demikian, rumusan hipotesis ketiga yang dinyatakan sebelumya "Terdapat pengaruh yang positif dan signifikan Pelatihan $\left(\mathrm{X}_{1}\right)$ dan Disiplin Kerja $\left(\mathrm{X}_{2}\right)$ secara bersamasama berpengaruh terhadap Kinerja karyawan (Y) pada PT Surya Mustika Nusantara", terbukti kebenarannya. nilai konstanta a dan koefesien b yang ditunjukkan pada perhitungan regresi linier berganda di atas dapat dihitung ke dalam rumus sebagai berikut: $\hat{Y}=46.181+0.092 .\left(\mathrm{X}_{1}\right)+0.182$ . $\left(\mathrm{X}_{2}\right)$

Diketahui nilai konstanta 46.181. Ini berarti pada Pelatihan dan Disiplin kerja lebih meningkat maka Kinerja karyawan pun akan bertambah. koefesien regresi untuk Pelatihan (0.092) lebih kecil daripada koefesien regresi untuk Disiplin kerja (0.128). Jadi bila Pelatihan dan Disiplin kerja lebih meningkat, maka kinerja karyawan menjadi :

$$
\begin{aligned}
\hat{Y} & =46.181+0.092 .(1)+0.182 .(1) \\
& =46.181+0.092+0.182=46.455
\end{aligned}
$$

Hal tersebut, memberikan gambaran bahwa arah hubungan antara Pelatihan dan Disiplin kerja ternyata searah, dimana setiap kenaikan satu satuan pada variable bebas (Pelatihan dan
Disiplin kerja) akan menyebabkan kenaikan terhadap variable terikat (Kinerja karyawan) sebesar 46.455 Artinya bila Pelatihan dan Disiplin kerja dapat dioptimalkan/ditingkatkan lebih baik, maka kinerja karyawan PT Surya Mustika Nusantara lebih bertambah meningkat.

\section{SIMPULAN}

\section{Kesimpulan}

1. Pengujian hipotesis ke 1 Pengaruh Pelatihan $\left(\mathrm{X}_{1}\right)$ Terhadap Kinerja karyawan $(\mathrm{Y})$ Hasil uji korelasi menunjukkan adanya pengaruh yang positif dan signifikan antara Pelatihan $\left(\mathrm{X}_{1}\right)$ Terhadap Kinerja karyawan (Y). Bila Pelatihan $\left(\mathrm{X}_{1}\right)$ meningkat/ ditingkatkan hingga mendapat nilai 1, maka Kinerja karyawan $(\mathrm{Y})$ menjadi : $\hat{\mathrm{Y}}=54.015+$ 0.080. $1=55.095$ Jadi diperkirakan Kinerja karyawan akan meningkat sebesar 55.095 . Dengan demikian, Kinerja karyawan akan naik, bila Pelatihan lebih meningkat. Hal ini membuktikan bahwa variable indevenden $\mathrm{X}_{1}$ (Pelatihan) searah terhadap naiknya turunnya variable dependent Y (Kinerja karyawan).

2. Pengujian hipotesis ke 2 Pengaruh Disiplin $\left(\mathrm{X}_{2}\right)$ Terhadap Kinerja karyawan $(\mathrm{Y})$ menunjukkan adanya pengaruh yang positif dan signifikan antara Disiplin $\left(\mathrm{X}_{2}\right)$ Terhadap Kinerja karyawan (Y). Jadi bila Disiplin $\left(\mathrm{X}_{2}\right)$ meningkat/ditingkatkan hingga mendapat nilai 1, maka Kinerja karyawan (Y) menjadi $: \hat{Y}=51.769+0.125 .1=52.894$. Jadi diperkirakan Kinerja karyawan akan meningkat sebesar 52.894. Dengan demikian, Kinerja karyawan akan naik, bila Pelatihan lebih meningkat. Hal ini membuktikan bahwa variable indevenden $\mathrm{X}_{2}$ (Disiplin) searah terhadap naiknya turunnya variable dependent $Y$ (Kinerja karyawan).

3. Pengujian hipotesis ke 3 Pengaruh Pelatihan $\left(\mathrm{X}_{1}\right)$ dan Disiplin $\left(\mathrm{X}_{2}\right)$ Terhadap Kinerja karyawan (Y) pengujian korelasi berganda menunjukkan bahwa nilai sig. (2-tailed) antara Pelatihan $\left(\mathrm{X}_{1}\right)$ dengan Kinerja karyawan (Y) adalah sebesar 0,002 
$<0,05$ yang berarti terdapat korelasi yang signifikan antara variable pelatihan dengan variable kinerja karyawan. Hubungan antara Pelatihan dan Disiplin kerja ternyata searah, dimana setiap kenaikan satu satuan pada variable bebas (Pelatihan dan Disiplin kerja) akan menyebabkan kenaikan terhadap variable terikat (Kinerja karyawan) sebesar 46.455 Artinya bila Pelatihan dan Disiplin kerja dapat dioptimalkan/ditingkatkan lebih baik, maka kinerja karyawan PT Surya Mustika Nusantara lebih bertambah meningkat.

\section{Saran}

1. PT. Surya Mustika Nusantara - Tangerang Selatan harus lebih mengendepankan pelatihan serta edukasi prosedur operasional perusahaan kepada setiap karyawan yang ada, agar kedisiplinan karyawan meningkat.

2. PT. Surya Mustika Nusantara- Tangerang Selatan harus lebih meningkatkan kedisiplinan kepada karyawannya.

3. PT. Surya Mustika Nusantara- Tangerang Selatan harus lebih mengoptimalkan kinerja karyawan agar kinerja karyawan lebih meningkat.

\section{DAFTAR PUSTAKA}

A.A. Anwar Prabu Mangkunegara. 2013. Manajemen Sumber Daya Manusia. Bandung: PT. Remaja Rosdakarya.

Agusta, L; E. M. Susanto (2013), Pengaruh Pelatihan dan Motivasi Kerja Terhadap Kinerja Karyawan CV Haragon Surabaya. AGORA, 1 (3).

Arifin \& Barnawi. 2012. Etika dan Profesi Kependidikan. Yogyakarta : Ar-ruzz Media

Arikunto, Suharsimi. 2010. Prosedur Penelitian Suatu Pendekatan Praktek. Jakarta. PT Bina Aksara

Bernadin, John H. \& Russel Joyce E. A. 1998. Human Resource Management: An Experiental Approach, 2nd edition. Singapore: The McGraw-Hill Companies,

Duwi, Priyatno. 2014. SPSS 02 Pengolah Data Terpraktis. Yogyakarta: ANDI.
Hasibuan, Melayu. 2010. Manejemen Sumber Daya Manusia. Bumi Aksara, Jakarta

Hasibuan, Malayu S.P. (2011) Manajemen: Dasar, Pengertian dan Masalah. Edisi Revisi. Jakarta: Bumi Aksara.

Hasibuan, Melayu. 2013. Manejemen Sumber Daya Manusia. Bumi Aksara, Jakarta

Mangkunegara Prabu, (2012). Evaluasi Kinerja SDM. Bandung: Refika Aditama

Mathis Robert, Jackson Jhon. 2002. Manejemen Sumber Daya Manusia. Jakarta. Salemba empat

Nazir Mohammad. 2003. Metode Penelitian. Jakarta: Ghalia Indonesia

Sedarmayanti, (2013). Manajemen Sumber Daya Manusia. Bandung: Refika Aditama

Simanjuntak, Payaman J. 2005. Manajemen dan Evaluasi Kinerja. Jakarta: FE UI.

Simamora, Henry. 1997. Manajemen Sumber Daya Manusia Edisi Kedua. Yogyakarta: STIE YKPN.

Singarimbun, Masri, dan Effendi. 1995. Metode Penelitian Survei. Cetakan Kedua. Jakarta: PT. Pustaka LP3ES Indonesia.

Sugiono. 2003. Metode Penelitian Administrasi: dilengkapi dengan Metode $R$ \& B. Bandung: Alfabeta

Sugiyono. 2010. Metode Penelitian Kuantitatif, kualitatif dan R \& D. Bandung: Alfabeta.

Sugiyono. 2012. Metode Penelitian Kuantitatif, kualitatif dan $R \& D$. Bandung: Alfabeta.

Undang-undang Republik Indonesia No. 13 Tahun 2003 Tentang Ketenagakerjaan. 